\title{
Benefits of Public R \& D in US Agriculture: Spill-Ins, Extension, and Roads*
}

\author{
Sunling Wang1\#, Alejandro Plastina ${ }^{2}$, Lilyan E. Fulginiti ${ }^{3}$, Eldon Ball ${ }^{1}$ \\ ${ }^{1}$ Economic Research Service, USDA, Washington, DC, USA \\ ${ }^{2}$ Department of Economics, Iowa State University, Ames, IA, USA \\ ${ }^{3}$ Department of Agricultural Economics, University of Nebraska-Lincoln, Lincoln, NE, USA \\ Email: "slwang@ers.usda.gov
}

How to cite this paper: Wang, S.L., Plastina, A., Fulginiti, L.E. and Ball, E. (2017) Benefits of Public R \& D in US Agriculture: Spill-Ins, Extension, and Roads. Theoretical Economics Letters, 7, 1873-1898. https://doi.org/10.4236/tel.2017.76128

Received: September 18, 2017

Accepted: October 28, 2017

Published: October 31, 2017

Copyright ( 2017 by authors and Scientific Research Publishing Inc. This work is licensed under the Creative Commons Attribution International License (CC BY 4.0).

http://creativecommons.org/licenses/by/4.0/

\begin{abstract}
This paper uses panel data for the 1980-2004 period to estimate the contributions of public research to US agricultural productivity growth. Local and social internal rates of return are estimated accounting for the effects of $\mathrm{R} \& \mathrm{D}$ spill-in, extension activities and road density. $\mathrm{R} \& \mathrm{D}$ spill-in proxies were constructed based on both geographic proximity and production profile to examine the sensitivity of the rates of return to these alternatives. We find that extension activities, road density, and R \& D spill-ins, play an important role in enhancing the benefit of public $\mathrm{R} \& \mathrm{D}$ investments. We also find that the local internal rates of return, although high, have declined through time along with investments in extension, while the social rates have not. Yet, the social rates of return are not robust to the choice of spill-in proxy.
\end{abstract}

\section{Keywords}

US Agricultural Productivity, Public R \& D, Spill-Ins, Extension, Roads, Internal Rate of Return, Cost Function

\section{Introduction}

Since the pioneering work by Griliches [1] [2] and Evenson [3], several empirical studies have shown that public investment in agricultural research and development (R \& D) is a primary driver of productivity growth. No matter the methodology used, analysts are in agreement that returns to investments in agricultural research are high, though the rates of return may differ depending on the research program or the data used to estimate returns. In a literature survey,

*The views expressed are those of the author(s) and should not be attributed to the Economic Research Service or USDA. 
Alston et al. [4] found that the median of the estimated rate of return to agricultural research was 48 percent per year. Huffman and Evenson [5] reviewed studies of the US agricultural sector covering the 1965-2005 period and found that, on average, the social rate of return was more than 50 percent per annum. Fuglie and Heisey [6] reviewed studies on Federal-State investment in agricultural research. They reported that the rates of return are in range of 20 to 60 percent for most studies.

Previous studies on the contribution of $\mathrm{R} \& \mathrm{D}$ to productivity growth can be grouped into four main categories. First, there are international studies [7] [8] [9] versus single country studies [2] [10]; second, there are studies that construct knowledge stocks using patent data [8] [11] [12] versus data on R \& D expenditures [13] [14] [15] [16]; third, there are those studies that focus on individual commodities or commodity programs [1] [17] [18] [19] versus aggregate output [20] [21]; and fourth, there are studies that directly incorporate an R \& D stock variable in the estimation of a production or cost function [22] [23] versus those that use a two-step procedure regressing an index of productivity growth on R \& D stocks [14] [15] [24].

Methodological differences aside, many of these studies point to significant technology spillovers across geographic boundaries. While the contribution of $\mathrm{R}$ \& D spill-ins ${ }^{1}$ to US agricultural productivity growth from nearby states is widely recognized, it is less clear why productivity growth in some states with similar characteristics and with similar potential R \& D spill-ins is faster than in other states. Nor is it clear through which channels technical knowledge is disseminated. Some studies ([24] [25] [26] [27] [28]) have emphasized the important role of the extension service in promoting productivity growth. Antle [29] and Paul et al. [30] suggest that road infrastructure can also be an important contributor to productivity growth. Yet, aside from addressing the important role of extension, R \& D spill-ins, or road infrastructure on productivity growth, not many have addressed the question of how the return to public $R \& D$ is enhanced by R \& D spill-ins, extension, and roads. There are also very few studies addressing the impact of alternative proxies to capture research spill-ins since measures based on geographic proximity have become the norm.

The objectives of this paper are, first, to study the interaction between local (i.e., own) R \& $\mathrm{D}$ and $\mathrm{R} \& \mathrm{D}$ spill-ins, extension activities, and road density ${ }^{2}$. Second, we estimate the own as well as social internal rates of return to investment in research in each state. Third, we develop alternative estimates of potential R \& D spill-in variables based on geographic proximity and production profile similarity, to investigate sensitivity of the rates of return to these alternative proxies. Finally, we evaluate how changes in extension activities and in road density affect the estimated internal rates of return.

${ }^{1} \mathrm{R} \& \mathrm{D}$ Spill-ins are R \& D knowledge stocks developed by other states. See data section for details regarding alternative $\mathrm{R} \& \mathrm{D}$ spill-ins measures in the study.

${ }^{2}$ See the Data section below for a precise definition of each of these variables. 
We model technology in agriculture by a dual cost function using a panel of US states. Knowledge stocks, measured as the accumulation of past research expenditures, are treated as a public (i.e., exogenous) capital input. We treat R \& D spill-ins, extension, and infrastructure differently from own $\mathrm{R} \& \mathrm{D}$ because we think that while own R \& D is fully usable by state these "efficiency" variables are only partially usable and enter the cost function through interaction terms with local R \& D stock.

We find that, although sensitive to the alternative proxies for knowledge spill-ins, the internal rates of return to $\mathrm{R} \& \mathrm{D}$ investments in US agriculture have been persistently high. Moreover, the rates of return are enhanced through the interaction of own R \& D with extension activities, knowledge spill-ins, and road density.

\section{Model}

A number of model specifications have been used to assess the contribution of public R \& D to US agricultural productivity. Some have first constructed an index of productivity growth and, in a two-step procedure, related this index to $\mathrm{R}$ \& D investments [14] [15] [16] [24]. Still others have estimated the production or dual cost function to obtain simultaneously a measure of productivity growth of the sector and R \& D's contribution to that growth [21] [27] [30] [31]. In this study, we specify a dual cost function and incorporate own R \& D stock, as well as its interactions with R \& D spill-ins from other states, extension activities, and road density.

While local investment in public agricultural research is viewed as a major driver of technological advancement, investment in research in other states, especially those with similar production characteristics, also contributes to local productivity growth. This effect is generally referred to as a research "spill-in" from other states. We assume that research spill-ins, along with extension activities and the road network, interact with local public research to enhance diffusion and absorption of technical information. An intensive road network can provide farmers with an easier and less costly way to acquire new technologies by attending workshops or other extension activities. It can also save on the time it takes the extension staff to contact producers around the state. Given the development of internet technology and broadband investment, extension staff now have more ways to directly strengthen and speed the dissemination and absorption of technical information. Similarly, research spill-ins from nearby states as well as from states with similar production profiles could provide a "cluster" effect and generate a multipliable impact with local $\mathrm{R} \& \mathrm{D}$ on productivity growth. In this way, these factors may act as catalysts in stimulating diffusion and utilization of technical information.

We proceed by estimating a translog cost function using state-by-year panel data. We then derive estimates of productivity growth that capture the impact of local R \& D investments as well as the magnifying effects of R \& D spill-ins, ex- 
tension activities, and infrastructure. Given its importance, we pay particular attention to construction of R \& D spill-in variables. Finally, we estimate statelevel internal rates of return to public agricultural research.

We assume that each state produces three outputs, livestock (V), crops (C) and other farm related goods and services $(\mathrm{O})$, using four variable inputs including land (A), labor (L), materials (M), and capital (K), and one fixed input, own agricultural $\mathrm{R} \& \mathrm{D}$ stock (RD). We include interactions between own R \& D and extension activities (ET), road density (RO), and R \& D spill-ins (SR), which we term "efficiency variables" (E). These variables have the potential of increasing the marginal productivity of local R \& D capital. The translog variable cost function is:

$$
\begin{aligned}
\ln T V C= & \alpha_{0}+\sum_{n=1}^{10} \sum_{i=1}^{4} \alpha_{n i} D_{n} \ln w_{i}+\sum_{l=1}^{3} \beta_{l} \ln y_{l}+\gamma_{R D} \ln R D+\frac{1}{2} \gamma_{R D R D} \ln R D \ln R D \\
& +\frac{1}{2} \sum_{i=1}^{4} \sum_{j=1}^{4} \alpha_{i j} \ln w_{i} \ln w_{j}+\frac{1}{2} \sum_{l=1}^{3} \sum_{k=1}^{3} \beta_{l k} \ln y_{l} \ln y_{k}+\sum_{i=1}^{4} \sum_{l=1}^{3} \delta_{i l} \ln w_{i} \ln y_{l} \\
& +\sum_{i=1}^{4} \theta_{i R D} \ln w_{i} \ln R D+\sum_{l=1}^{3} \phi_{l R D} \ln y_{l} \ln R D+\sum_{h=1}^{3} \xi_{h R D} \ln E_{h} \ln R D \\
& +\sum_{h=1}^{3} \sum_{i=1}^{4} \rho_{i h} \ln E_{h} \ln w_{i}+\sum_{i=1}^{4} \rho_{i W} \ln P \ln w_{i}
\end{aligned}
$$

where the $W^{\prime} s$ are input prices, the 'y's are output quantities, $R D$ is the own-state $\mathrm{R} \& \mathrm{D}$ stock, the $E s$ are efficiency variables, the $D^{\prime} s$ are regional dummy variables, and $P$ is a measure of rainfall. We introduce regional dummies in the first-order terms to allow for differences in cost shares across the production regions. The regions are the USDA's farm production regions defined in Table 1.

Symmetry and linear homogeneity in prices are imposed during estimation. Using Shephard's lemma, the cost share for input $i$ is:

$$
S_{i}=\sum_{n=1}^{10} \alpha_{n i} D_{n}+\sum_{j=1}^{4} \alpha_{i j} \ln w_{j}+\sum_{l=1}^{3} \delta_{i l} \ln y_{l}+\theta_{i R D} \ln R D+\sum_{h=1}^{3} \rho_{i h} \ln E_{h}+\rho_{i W} \ln P
$$

Table 1. USDA's production regions.

\begin{tabular}{cc}
\hline Region & States \\
\hline Northeast & NH, PA, ME, MD, RO, MA, DE, CT, VT, NY, NJ \\
Lake States & MN, MI, WI \\
Corn Belt & OH, IA, MO, IN, IL \\
Appalachian & WV, TN, NC, VA, KY \\
Southeast & SC, AL, GA, FL \\
Delta & LA, AR, MS \\
Northern Plains & ND, SD, KS, NE \\
Southern Plains & TX, OK \\
Mountain & CO, UT, AZ, NM, WY, NV, ID, MT \\
Pacific & OR, CA, WA \\
\hline
\end{tabular}

Data source: USDA. 
The estimated system of equations includes the total variable cost Equation (1) and the input cost share Equation (2). Additive disturbances are appended to each share equation and the variable cost function. These disturbances are presumed temporally independent, multivariate normal with zero mean and nonzero contemporaneous covariances. The contemporaneous covariance matrix of the disturbance terms of the cost and share equations is singular since the cost shares must sum to unity at every sample point. Hence, a single share equation is dropped in estimation. The system of equations is estimated using the Iterative Seemingly Unrelated Regression (ITSUR) algorithm in SAS. The estimation results are independent of the equation dropped under the maintained assumptions on the error structure.

Price responsiveness can be measured by the input price elasticities of derived demand $(\eta)$ :

$$
\begin{gathered}
\eta_{i i}=\frac{\alpha_{i i}+s_{i}^{2}-s_{i}}{s_{i}}, i=1, \cdots, N, \\
\eta_{i j}=\frac{\alpha_{i j}+s_{i} s_{j}}{s_{i}}, i, j=1, \cdots, N, i \neq j,
\end{gathered}
$$

where $S_{i}$ and $S_{j}$ are the fitted cost shares for inputs $i$ and $j$. The marginal cost elasticity $(e)$ is also estimated:

$$
e_{l}=\frac{\partial \ln T V C}{\partial \ln Y_{l}}=\beta_{l}+\sum_{k=1}^{3} \beta_{l k} \ln y_{k}+\sum_{i=1}^{4} \delta_{i l} \ln w_{i}+\phi_{I R D} \ln R D, \quad l=1,2,3
$$

as are the cost elasticities $(\varepsilon)$ with respect to local R \& D stocks and the efficiency variables $\left(E_{h}\right)$ - spill-in stocks $(S R)$, extension activities $(E T)$, and road density $(R O)$ :

$$
\begin{gathered}
\varepsilon_{R D}=\frac{\partial \ln T V C}{\partial \ln R D}=\gamma_{R D}+\gamma_{R D R D} \ln R D+\sum_{i=1}^{4} \theta_{i R D} \ln w_{i}+\sum_{l=1}^{3} \phi_{I R D} \ln y_{l}+\sum_{h=1}^{3} \xi_{h R D} \ln E_{h} \\
\varepsilon_{E_{h}}=\frac{\partial \ln T V C}{\partial \ln E_{h}}=\sum_{h=1}^{3} \xi_{h R D} \ln R D+\sum_{i=1}^{4} \rho_{i E_{h}} \ln w_{i}
\end{gathered}
$$

As noted above, one of the effects that we would like to highlight in this study is the interaction between local R \& D stocks and the efficiency variables. This cross effect is:

$$
M E_{E_{h} R D}=\frac{\partial \varepsilon_{R D}}{\partial \ln E_{h}}=\sum_{h=1}^{3} \xi_{h R D}
$$

If $\varepsilon_{R D}$ or $\varepsilon_{E}$ is negative, then an increase in local R \& D stock or any of the efficiency variables $E_{h}$ reduces total variable cost, given input prices and output levels. If $M E_{E_{h} R D}$ is negative then the efficiency variables have a further cost reducing effect; they magnify the cost-reducing impact of own $\mathrm{R} \& \mathrm{D}$, as hypothesized.

\section{Internal Rate of Return to Agricultural Research}

To evaluate the benefits of public research, we proceed to calculate the internal 
rate of return $(\mathrm{IRR})^{3}$, which is the rate of discount that makes the net present value of all cash flows (including both inflows and outflows) from a particular investment equal to zero. In other words, the IRR of an investment is the rate of discount at which the present value of the stream of benefits equals the initial investment. In this framework of analysis, benefits are measured as cost savings $(-\Delta T V C)$. Furthermore, an investment in public $\mathrm{R} \& \mathrm{D}(R)$ at time $t$ is assumed to increase the stock of local $\mathrm{R} \& \mathrm{D}(R D)$ in $t+\tau \quad(\tau=0, \cdots, s)$ at a rate of:

$$
\frac{\Delta R D_{t+\tau}}{\Delta R_{t}}=\omega_{\tau}
$$

Therefore, the local internal rate of return is the rate $r_{1}$ that solves the following formula:

$$
\begin{aligned}
1 & =\sum_{\tau=0}^{s} \frac{-\Delta T V C_{t+\tau}}{\Delta R_{t}} \cdot \frac{1}{\left(1+r_{1}\right)^{\tau}}=\sum_{\tau=0}^{s} \frac{-\Delta T V C_{t+\tau}}{\Delta R D_{t+\tau}} \cdot \frac{\Delta R D_{t+\tau}}{\Delta R_{t}} \cdot \frac{1}{\left(1+r_{1}\right)^{\tau}} \\
& =\sum_{\tau=0}^{s} \frac{-\Delta T V C_{t+\tau}}{\Delta R D_{t+\tau}} \cdot \frac{\omega_{\tau}}{\left(1+r_{1}\right)^{\tau}}
\end{aligned}
$$

The impact of a one-dollar increase in a state's local public agricultural R \& D stock $(R D)$ on that state's total variable cost ( TVC) can be approximated as (for simplicity the time subscript $t$ is dropped):

$$
\frac{\Delta T V C}{\Delta R D}=\frac{\partial \ln T V C}{\partial \ln R D} \frac{T V C}{R D}
$$

To obtain the local internal rate of return we substitute (6) into (10), and solve for $r_{1}$ :

$$
\begin{aligned}
1= & -\sum_{\tau=0}^{s}\left[\gamma_{R D}+\gamma_{R D R D} \ln R D_{t+\tau}+\sum_{i=1}^{4} \theta_{i R D} \ln w_{t+\tau, i}+\sum_{l=1}^{3} \phi_{l R D} \ln y_{t+\tau, l}\right. \\
& \left.+\sum_{h=1}^{3} \xi_{h R D} \ln E_{t+\tau, h}\right] \cdot \frac{T V C_{t+\tau}}{R D_{t+\tau}} \cdot \frac{\omega_{\tau}}{\left(1+r_{1}\right)^{\tau}}
\end{aligned}
$$

Given that $\mathrm{R} \& \mathrm{D}$ investments in agriculture have the characteristics of an impure public good ${ }^{4}$, the relevant concept in evaluation should include not only the local benefits (cost-savings) but also the benefits reaped by other states through $\mathrm{R} \& \mathrm{D}$ spillovers (i.e., the social rate of return). Taking into account both effects, the social internal rate of return, $r_{2}$, is derived by solving for $r_{2}$ in the following equation:

$$
1=\sum_{\tau=0}^{s} \frac{-\Delta T V C_{f, t+\tau}}{\Delta R_{f, t}} \cdot \frac{1}{\left(1+r_{2}\right)^{\tau}}-\sum_{g \neq f}^{q-1} \sum_{\tau=0}^{s} \frac{\Delta T V C_{g, t+\tau}}{\Delta R_{f, t}} \cdot \frac{1}{\left(1+r_{2}\right)^{\tau}}
$$

where $f$ indicates the state that makes the investment in public $\mathrm{R} \& \mathrm{D}, g$ indexes the states hypothesized to benefit from the spillovers from the research investment in state $f$, and $q$ indicates the total number of states that benefit from the

${ }^{3}$ Most studies have calculated internal rates of return, although the study by Alston et al. [15] has also calculated a modified internal rate of return [32]. For a detailed discussion of the IRR rule in investment projects see Chapter 8 in Brealey, Myers, and Marcus [33].

${ }^{4}$ Pure public goods are non-excludable and non-rival. Public research in other states, though "public", is not fully non-excludable, and therefore an "impure public good" [34]. 
research investment in state $f$ (including $f$ ). The first term in (13) is similar to Equation (12), and represents the local benefits. The second term in (13) captures the social benefits in other states generated by state $f s$ local research investment. The second term in Equation (13) can be alternatively expressed as:

$$
-\sum_{g \neq f}^{q-1} \sum_{\tau=0}^{s} \frac{\Delta T V C_{g, t+\tau}}{\Delta R_{f, t}} \cdot \frac{1}{\left(1+r_{2}\right)^{\tau}}=-\sum_{g \neq f}^{q-1} \sum_{\tau=0}^{s} \frac{\Delta T V C_{g, t+\tau}}{\Delta S R_{g, t+\tau}} \cdot \frac{\Delta S R_{g, t+\tau}}{\Delta R_{f, t}} \cdot \frac{1}{\left(1+r_{2}\right)^{\tau}}
$$

The R \& D spill-in stock for state $f\left(S R_{f}\right)$ is constructed as a weighted sum of contemporaneous local R \& D stocks in other states:

$$
S R_{f, t}=\sum_{g \neq f}^{q-1} \Omega_{f g} R D_{g, t}
$$

where $\Omega_{f g}$ are the weights used to capture the $g^{\text {th }}$ state's R \& D stock contribution to state's $f$ spill-in stock. Therefore, the change in spill-ins stocks in state $g$ at time $t+\tau$ from an investment in $\mathrm{R} \& \mathrm{D}$ in state $f$ at time $t$ is:

$$
\frac{\Delta S R_{g, t+\tau}}{\Delta R_{f, t}}=\frac{\Delta S R_{g, t+\tau}}{\Delta R D_{f, t+\tau}} \frac{\Delta R D_{f, t+\tau}}{\Delta R_{f, t}}=\Omega_{g f} \omega_{\tau}
$$

The impact of research spill-ins from other states on state $g^{\prime} s$ total variable cost can be approximated as follows (excluding time indexes for simplicity):

$$
\frac{\Delta T V C}{\Delta S R}=\frac{\partial \ln T V C}{\partial \ln S R} \frac{T V C}{S R}
$$

We obtain the social internal rate of return by substituting (6) and (7) into (11) and (17), correspondingly, and substituting those results and (16) into (14), and solving for $r_{2}$ :

$$
\begin{aligned}
1= & -\sum_{\tau=0}^{s}\left[\gamma_{R D}+\gamma_{R D R D} \ln R D_{f, t+\tau}+\sum_{i=1}^{4} \theta_{i R D} \ln w_{f, t+\tau, i}+\sum_{l=1}^{3} \phi_{I R D} \ln y_{f, t+\tau, l}\right. \\
& \left.+\sum_{h=1}^{3} \xi_{h R D} \ln E_{f, t+\tau, h}\right] \cdot \frac{T V C_{f, t+\tau}}{R D_{f, t+\tau}} \cdot \frac{\omega_{\tau}}{\left(1+r_{2}\right)^{t+\tau}} \\
& +\sum_{g \neq f}^{q-1} \sum_{\tau=0}^{s}\left(\xi_{S R R D} \ln R D_{g, t+\tau}+\sum_{i=1}^{4} \rho_{i, S R} \ln w_{g, t+\tau, i}\right) \cdot \frac{T V C_{g, t+\tau}}{S R_{g, t+\tau}} \cdot \frac{\Omega_{g f} \omega_{\tau}}{\left(1+r_{2}\right)^{t+\tau}}
\end{aligned}
$$

\section{Data}

\subsection{Output Quantities and Input Prices}

Our data consist of a panel of state-level observations spanning the years 1980 to 2004. This section provides a brief overview of data sources and aggregation procedures. Details on the data construction are in the USDA productivity web page [35] and Ball et al. [36].

State-specific aggregates of output and labor, capital and intermediate inputs are Törnqvist indexes over detailed output and input accounts. Törnqvist output indexes are formed by aggregating over agricultural goods and services using revenue-share weights based on shadow prices. The changing demographic character of the agricultural labor force is used to build a quality adjusted index of 
labor input. The measure of capital input begins with data on the stock of capital for each component of capital input. For depreciable assets, the capital stocks are the accumulation of all past investments adjusted for discards of worn-out assets and loss of efficiency of assets over their service life. For land and inventories, capital stocks are measured as implicit quantities derived from balance sheet data. Indexes of capital input are formed by aggregating over the various capital assets using cost share-weights based on assets-specific rental prices. Törnqvist indexes of energy consumption are calculated for each state by weighting the growth rates of petroleum fuels, natural gas, and electricity consumption by their share in the overall value of energy input. Fertilizers and pesticides are important intermediate inputs. Price indexes for fertilizers and pesticides are constructed using hedonic methods. The corresponding quantity indexes of fertilizers and pesticides are formed implicitly by taking the ratio of the value of each aggregate to its hedonic price index. A Törnqvist index of intermediate inputs is constructed for each state by weighting the growth rates of each category of intermediate inputs by their value share in the overall value of intermediate inputs. Finally, following Caves, Christensen, and Diewert [37], output and input indexes with spatial as well as temporal integrity are developed. The result is data for a panel of states that can be used for both cross section and time series analysis.

\subsection{Local R \& D}

There are many different methods used to construct knowledge stocks. In studies of the impact of private research in manufacturing, research stocks are frequently constructed from data on research expenditures using the perpetual inventory method. However, as noted by Griliches [38], the usual declining balance or geometric depreciation does not fit very well the likely gestation, blossoming, and eventual obsolescence of knowledge. He also notes that there is no agreement as to the best model to use in constructing R \& D stocks. Except for some studies that have based the construction on best statistical fit [4] [14] [39], most approaches are ad-hoc and based on intuition ${ }^{5}$.

We use a knowledge stock variable developed by Huffman that uses the trapezoidal distribution proposed by Huffman and Evenson [5] [40]. More specifically, this distribution assumes a 2 year gestation period, followed by 7 years of increasing impacts, 6 years of maturity with constant weights, and 20 years of decay with declining weights. Nominal research expenditures are deflated by an agricultural research price index. Index construction details can be found in [5] [41].

\subsection{R \& D Spill-Ins}

In this study, we use two public research stock variables, an own-state variable and an R \& D spill-in variable. Most studies that include potential spill-ins as${ }^{5}$ See [14] for a discussion on alternative shapes and lag length. These assumptions also have implications on the rates of return. 
sume that discoveries from public research in a given state are an impure public good and use one particular approach to calculate them. Most impose the simplifying assumption that research benefits are regionally confined and apply simple aggregation over USDA production regions (see [16] [24] [27] [31]). Studies by Alston et al. [14] [15] and Plastina and Fulginiti [21] are the exception. Alston et al. [14] [15] constructed this variable based on "similarity" of the production mix, while Plastina and Fulginiti [21] used a stochastic "concentric rings" approach.

Because this is a key variable in the calculation of social returns, and because other studies estimated rates of return using just one of these approaches, we construct four alternative measures of the R \& D spill-in variable. Our objective is to provide information on the sensitivity of the estimated rates of return to alternative models for the R \& D spill-in stocks. The first two approaches we use are based on geographic proximity ${ }^{6}$, while the last two reflect "production profile" similarities across states ${ }^{7}$. The differences in the $\mathrm{R} \& \mathrm{D}$ spill-in stocks reside in the weights used in (15), as described below:

Model 1: $\Omega_{f g}=1$ for state $j$ in the same USDA production region (Table 1). The R \& D spill-in stock for state $i$ is the sum of research stocks in all other states in that region.

Model 2: $\Omega_{f g}=1 /$ dist $_{f g}$ for an R \& D spill-in variable generated based on the geographic distance among states. This approach, inspired by gravity-type trade models [42], is offered to allow for a geographic "correction" to Model 1. The R \& D stock generated by a state is scaled using the inverse distance between the sending state and the receiving state. The distance between Montana and New Mexico is chosen as the cutoff distance. Any state $g$ with its geographical center within the cutoff distance from state $f$ s geographical center was assumed to have an impact on state $f s$ production and was given a weight equal to the inverse of the distance between two states, while states beyond that distance were assigned a zero weight.

Model 3: $\Omega_{f g}=1$ for states $f$ and $g$ within the same production profile cluster. We use cash receipts from twelve categories of outputs to generate a production profile for each state. The twelve outputs categories are: meat animals, dairy products, poultry/eggs, miscellaneous, food grains, feed crops, cotton, tobacco, oil crops, vegetables, fruits/nuts, and all other crops. We use cluster analysis to group the states with similar production profiles. While there are several clustering techniques, we use the complete linkage clustering method following Sorensen $[43]^{8}$. In complete linkage clustering, the distance between two clusters is the maximum distance between an observation in one cluster and an observation in the other cluster, considering multiple elements. It avoids the drawback

${ }^{6}$ Versions of the approach used by Huffman and Evanson and colleagues.

${ }^{7}$ Versions of the approach used by Alston and colleagues.

${ }^{8}$ While we prefer using the complete linkage method we compared results with those based on alternative cluster methods, such as the centroid method and the average linkage method ([44] among others). The results were similar so we only report the results based on the complete linkage method. 
of the single linkage method that may force states to be grouped together due to closeness in one single element while many other elements are very different. The procedure is implemented using the SAS econometric package and results are presented in Table 2. Under this methodology, distant states such as Florida and California are in the same group due to the similarity of their production profiles.

Model 4: $\Omega_{f g}=1 /$ Tecdist $_{f g}$ for an R \& D spill-in variable generated based on the technical distance among states within the same cluster from Model 3. Tecdist $_{f g}$ is the technological distance measured by the inverse of the Spearman correlation coefficient on the production mix among states. The higher is the correlation relationship, the smaller is the technical distance among states within the same cluster.

Descriptive statistics for the four R \& D spill-in variables, along with other efficiency variables described below, are presented in Table 3. In Figure 1, we show the alternative series of R \& D spill-in stocks for Alabama to give a sense of the different spill-in proxies. From information in Table 3 and in Figure 1, we

Table 2. Clusters for 48 States Based on Production Profile.

\begin{tabular}{cc}
\hline Cluster & States \\
\hline 1 & IA, IL, IN, MN, MO, NE, OH, SD \\
2 & CO, ID, KS, MI, NM, NV, OK, OR, TX, UT, WY \\
3 & AL, AR, DE, GA, MD, NC, SC, TN, VA, WV \\
4 & NY, VT, WI \\
5 & CT, NH, PA, RI \\
6 & AZ, LA, MS \\
7 & MT, ND \\
8 & KY \\
9
\end{tabular}

Data source: Developed by authors.

Table 3. Descriptive statistics for efficiency variables.

\begin{tabular}{ccccccc}
\hline statistics & extension & road density $\begin{array}{c}\text { R \& D spilii-in R \& D spilii-in R \& D spilii-in R \& D spilii-in } \\
\text { (Model 1) }\end{array}$ & $\begin{array}{c}\text { (Model2) } \\
\text { (Model3) }\end{array}$ & (Model4) \\
\hline (unit) & (FTE per farm) & $\begin{array}{c}\text { (mile per } \\
\text { square mile) }\end{array}$ & $\begin{array}{c}\text { (constant } \\
\text { dollars) }\end{array}$ & $\begin{array}{c}\text { (constant } \\
\text { dollars) }\end{array}$ & $\begin{array}{c}\text { (constant } \\
\text { dollars) }\end{array}$ & $\begin{array}{c}\text { (constant } \\
\text { dollars) }\end{array}$ \\
\hline N & 1200 & 1200 & 1200 & 1200 & 1200 & 1200 \\
MIN & 0.0000 & 0.0583 & $11,696,201$ & $100,129,407$ & 5406,608 & $1,270,725$ \\
MAX & 0.0476 & 2.5634 & $219,463,954$ & $1,155,346,530$ & $217,905,010$ & $175,632,026$ \\
MEAN & 0.0100 & 0.6193 & $86,160,408$ & $575,183,765$ & $119,101,019$ & $85,945,211$ \\
STD & 0.0069 & 0.4828 & $39,880,052$ & $239,590,346$ & $60,382,324$ & $48,655,117$ \\
\hline
\end{tabular}

Note: FTE indicates full time equivalent staff numbers. 


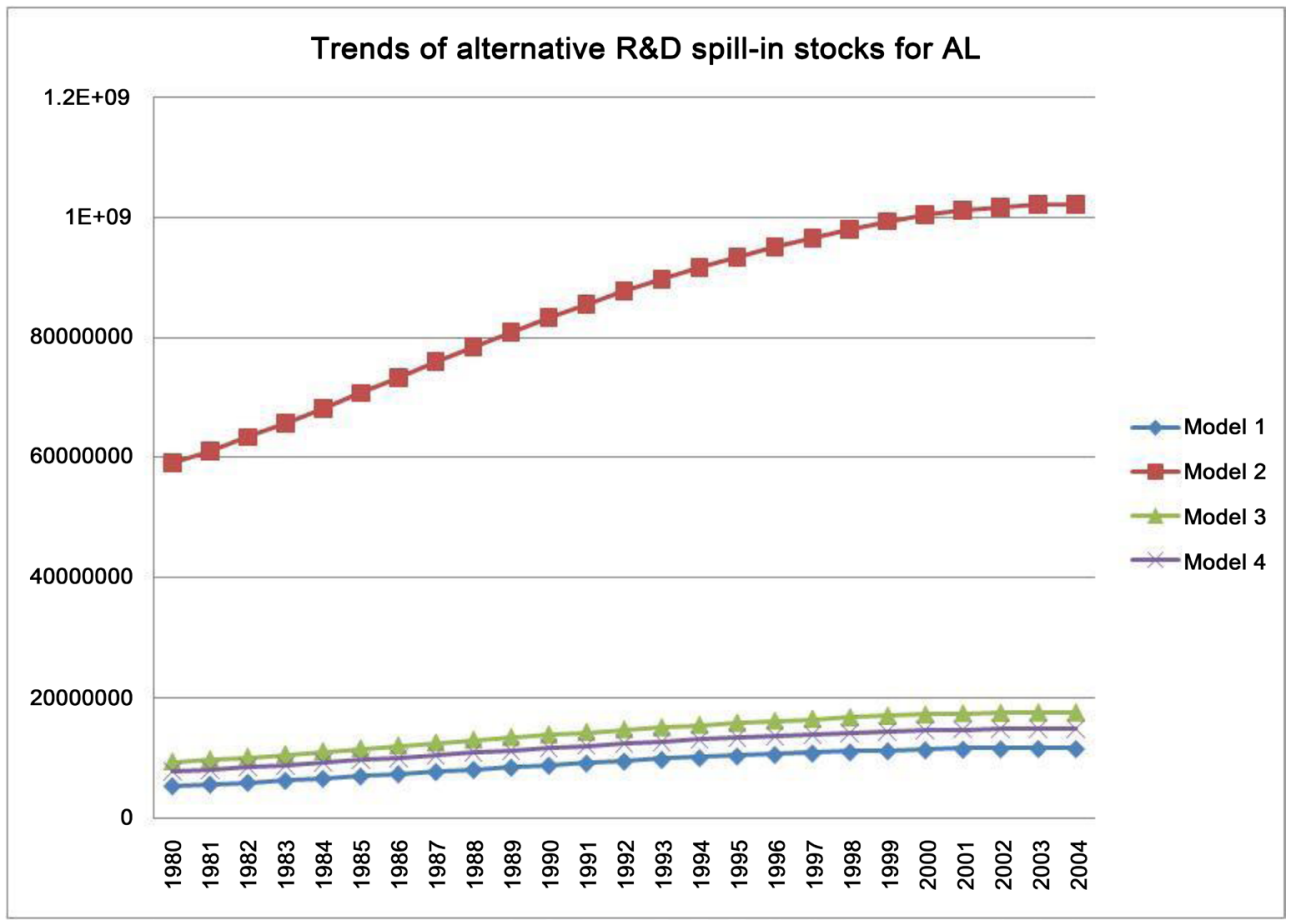

Figure 1. Trends for alternative R \& D spill-in stocks based on alternative measures for AL.

note that Model 2 yields a higher level of potential R \& D spill-in stocks than all other models mainly because it includes more states in its cluster.

\subsection{Extension}

Extension is measured by total extension full-time equivalent staff days per year (FTEs). Extension FTEs have declined between 1980 and 2010 at national and regional levels [42]. Figure 2 shows the extension FTEs trends for three states-CA, NE, MD. The declining trend is common in all of the 48 contiguous states ${ }^{9}$. Ahearn et al. [45] reported the series of state Extension FTEs for 1977-92 by 4 major program areas and by total state FTE's of extension staff for 1977-97. The disaggregated data are no longer available. We use total FTEs at the state level to construct the extension (ET) capacity indexes for each state. The extension capacity index uses total FTEs as the numerator and the number of farms as the denominator to capture scale differences ${ }^{10}$. Data on FTEs by state were drawn from [46]. No lags were included in the construction ${ }^{9}$ Jin and Huffman [16] show increasing trends for some individual states over time. The main differences between their variable and ours are: 1) the study period of Jin and Huffman covers 1970-2004 while this study covers 1980-2004. Although extension FTEs during 1970-1980 have increased in some states, they have mostly been either constant or lower starting in the 1980s; 2) [16] uses extension stock rather than current extension FTEs. The stock measures may have a slower declining trend as they are accumulations from previous extension investment. In this study we use FTEs from current years as we evaluate their interactions with concurrent R \& D stocks.

${ }^{10}$ Normalizing by number of farms has potential implications as number of farms as well as extension FTE's have been declining. It is also important to notice that along with the changes in farm size distribution and information technology, the nature of service has changed from one-on-one to group-level engagement. This change in delivery mode reflects the increasing public-good characteristic of the service provided. 


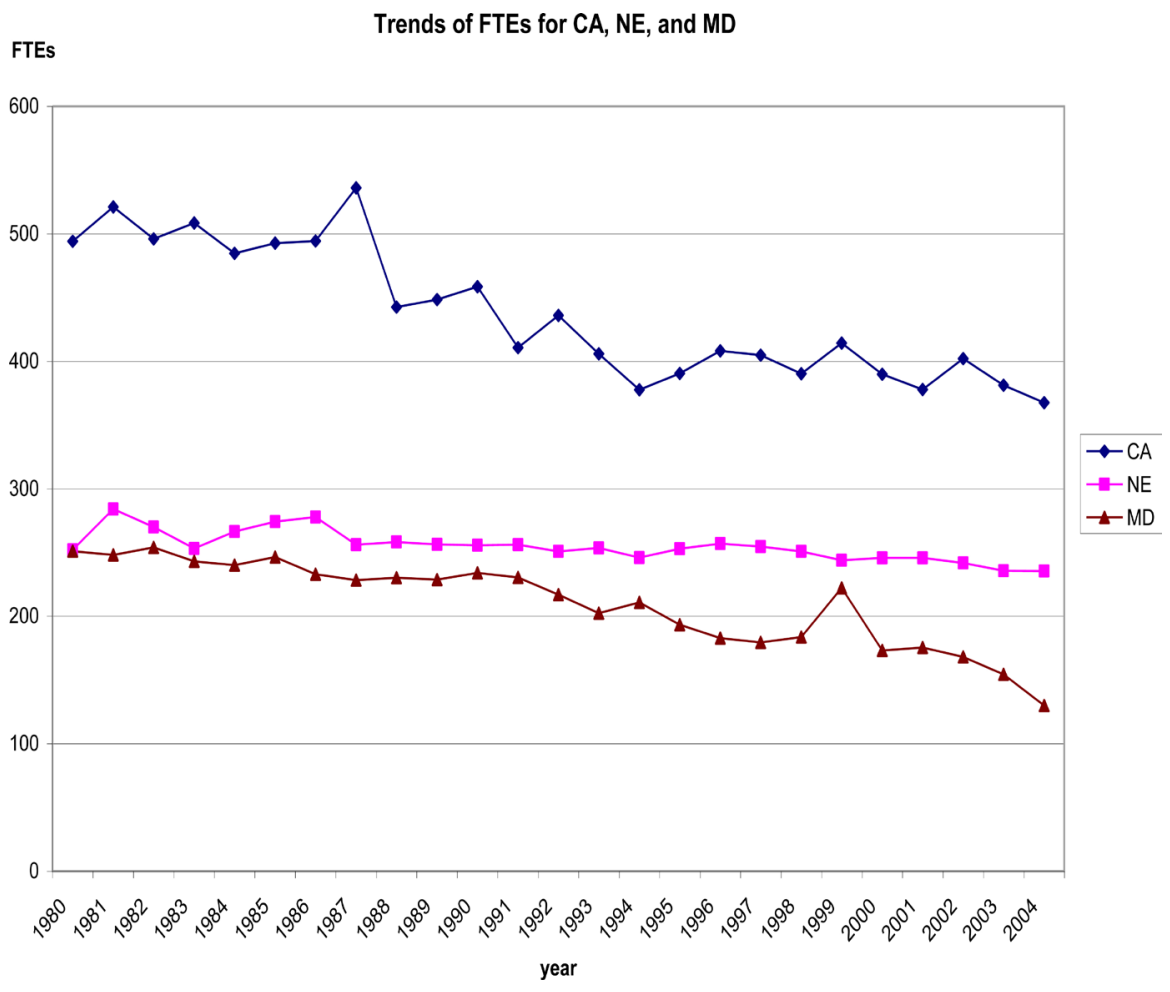

Figure 2. Trends of extension full-time equivalent staff days per year, 1980-2004 for CA, $\mathrm{NE}$, and MD.

of this variable ${ }^{11}$.

\subsection{Roads}

We construct a road density index to examine the impact of road infrastructure on dissemination of local $\mathrm{R} \& \mathrm{D}$. The state road density index was constructed using total annual road miles, excluding local (i.e. city street) miles for each state, obtained from [47], divided by total land area. We expect that with higher road density the cost of disseminating technical information is lower and the impact of public R \& D on productivity is enhanced. Figure 3 shows the evolution of this variable for five selected states-AL, CA, IA, IL, and MI. Although this variable is rather stable for each state, it varies considerably among states.

\subsection{Weather}

Weather is treated as a control variable in this model. While several alternative weather indexes have been applied to studies in the past, such as the Palmer index and the Stallings weather index, we use total precipitation in inches from March to November [48] [49].

\section{Empirical Results}

We estimate the variable cost function (1) and the cost share Equation (2) using

${ }^{11}$ While Huffman and colleagues use short lags in building the extension stock variable, Alston and colleagues use longer lags. 
Road Density for AL, CA, IA, IL, MI

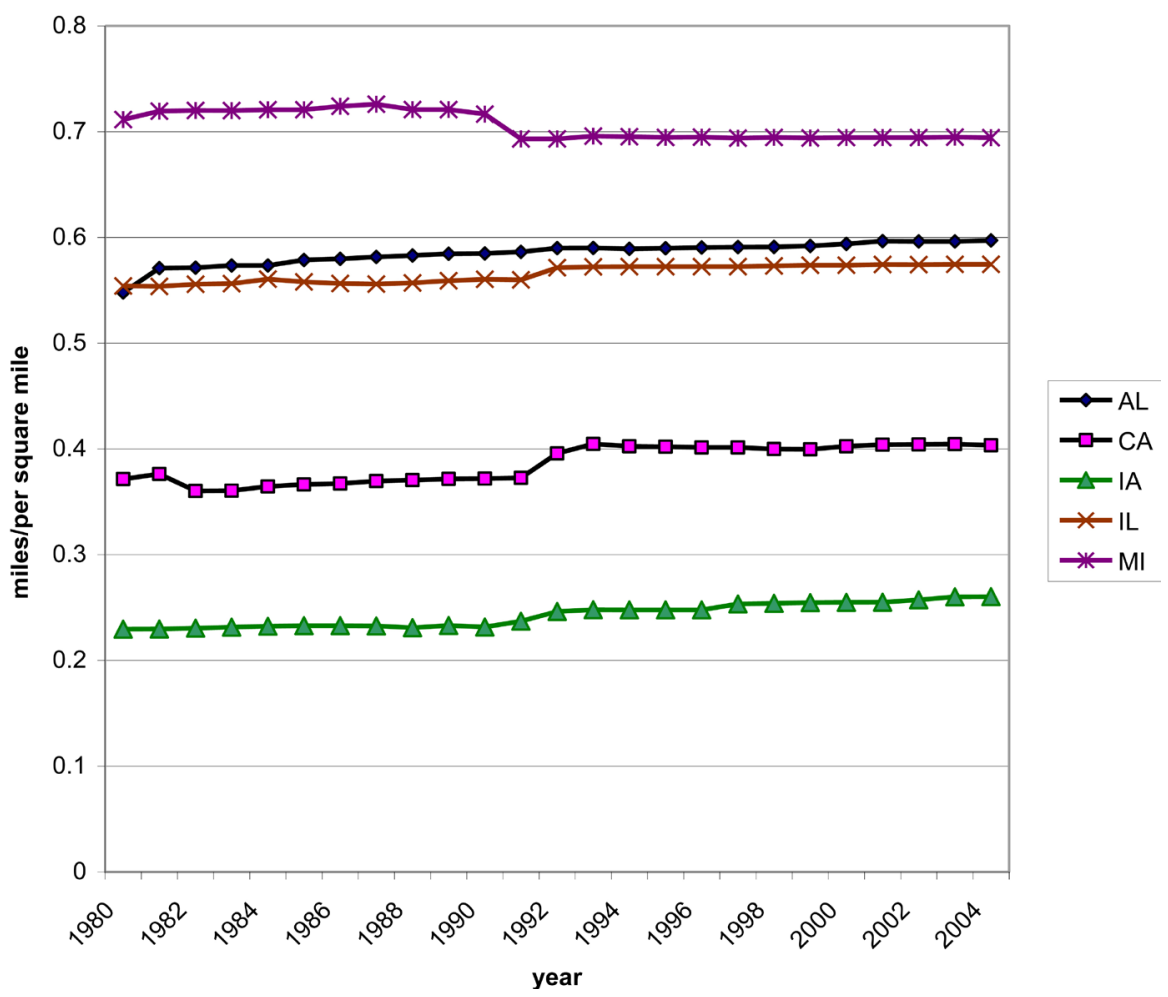

Figure 3. Road density for selected US states, 1980-2004.

the four alternative measures of $\mathrm{R} \& \mathrm{D}$ spill-ins defined above. Prior to estimation, we investigate the time series properties of the data. We conduct panel unit root tests proposed by Levin, Lin, and Chu [50]. All of the test statistics presented in Table 4 are less than the critical value at the 5\% level. Therefore, we reject the presence of a unit root and proceed by estimating Equations ((1) and (2)) assuming stationarity.

We then estimate a total of 100 parameters based on 1200 observation for each model subject to symmetry and linear homogeneity in input prices. The curvature and monotonicity properties of the cost function were inspected after estimation. Monotonicity was satisfied globally. Concavity in prices implies a negative semi-definite Hessian. We find that this condition holds locally.

In Table 5, we present the parameter estimates for the four models, excluding constant and interactive terms between regional dummies and input prices from each model. We note that 184 of the 236 parameter estimates for the four models are significant at the $5 \%$ confidence level. Moreover, the parameter estimates (other than those for the R \& D spill-in variables) are stable across the different model specifications, giving an indication of the robustness of the estimates. Finally, as can be seen in Table 5, the coefficients on the interactive terms between own R \& D and the efficiency variables (extension activities, roads, and R \& D spill-ins) are all significant except for the coefficient on the $\mathrm{R} \& \mathrm{D}$ spill-in variable in Model 2. The mean and standard deviation of the own-price elasticities, 
cross-price elasticities, output cost elasticities, and the Hessian over 1200 observations are reported in Appendix Table A1.

The impacts of public R \& D, extension activities, roads, and R \& D spill-ins on agricultural productivity growth can be examined through the alternative cost elasticities and the marginal effects of the efficiency variables on R \& D's cost saving effect. The cost elasticities of own $\mathrm{R} \& \mathrm{D}$, extension activities, road density, and R \& D spill-ins are all negative (see Table 6). From Table 6, we see that a 1-percent increase in own $\mathrm{R} \& \mathrm{D}$ reduces total variable cost by $0.13-0.15$ percent, depending on the model specification. Extension activities had the greatest impact on variable cost $(0.23 \%-0.25 \%)$, followed by the effect of R \& D spill-ins $(0.01 \%-0.16 \%)$ and road density $(0.04 \%-0.06 \%)$.

Table 7 presents the marginal effect of each efficiency variable on cost diminution through their interaction with own $\mathrm{R} \& \mathrm{D}$ (equation 8). The estimates are all significant at $1 \%$ level except when we proxy spill-ins using geographic distance (Model 2.) We find that an increase in extension activities, road density,

Table 4. Panel unit root tests of variables used in the study.

\begin{tabular}{|c|c|c|}
\hline Variables & LLC' Statistic ${ }^{1}$ & p-value \\
\hline LnTVC & -5.10 & 0.0000 \\
\hline $\mathrm{S}_{\mathrm{K}}$ & -8.65 & 0.0000 \\
\hline $\mathrm{S}_{\mathrm{L}}$ & -2.37 & 0.0090 \\
\hline $\mathrm{S}_{\mathrm{M}}$ & -1.78 & 0.0377 \\
\hline $\operatorname{LnV}$ & -2.86 & 0.0021 \\
\hline $\operatorname{LnC}$ & -3.88 & 0.0001 \\
\hline $\mathrm{LnO}$ & -9.75 & 0.0000 \\
\hline $\operatorname{LnRD}$ & -36.83 & 0.0000 \\
\hline LnET & -2.48 & 0.0066 \\
\hline LnRO & -4.71 & 0.0000 \\
\hline LnSR1 & -30.60 & 0.0000 \\
\hline LnSR2 & -34.84 & 0.0000 \\
\hline LnSR3 & -34.21 & 0.0000 \\
\hline LnSR4 & -34.65 & 0.0000 \\
\hline $\operatorname{Ln} A$ & -3.61 & 0.0002 \\
\hline $\operatorname{LnM}$ & -2.37 & 0.0088 \\
\hline $\operatorname{LnK}$ & -11.73 & 0.0000 \\
\hline $\operatorname{LnL}$ & -1.68 & 0.0462 \\
\hline LnW & -10.14 & 0.0000 \\
\hline
\end{tabular}

Note 1: The LLC panel unit root test is based on the method proposed by Levin, Lin, and Chu (2002). Our tests include a constant term for every variable except LnK. In the case of LnTVC, LnET, a time trend was included. Note 2: SR1, SR2, SR3 SR4 are alternative R \& D spillins based on the estimates from Model 1 through Model 4. Note 3: V stands for livestock, C for crops, O for other farm related goods and services, A for land, L for labor, $\mathrm{M}$ for materials, $\mathrm{K}$ for capital, RD for own agricultural R \& D stock, ET for extension, RO for road density, SR for R \& D spillins. 
Table 5. Coefficient Estimates of cost share equations, 48 states, US Agriculture, 1980-2004, alternative R \& D spill-in stocks.

\begin{tabular}{|c|c|c|c|c|c|c|c|c|c|c|c|c|}
\hline \multirow[b]{2}{*}{ Parameters } & \multicolumn{2}{|c|}{ Model 1} & \multicolumn{3}{|c|}{ Model 2} & & \multicolumn{2}{|c|}{ Model 3} & \multicolumn{4}{|c|}{ Model 4} \\
\hline & coefficients & t ratio & & coefficients & $\mathrm{t}$ ratio & & coefficients & t ratio & & coefficients & t ratio & \\
\hline$\beta_{\mathrm{V}}$ & 1.4720 & 5.46 & $* * *$ & 1.7428 & 6.11 & $* * *$ & 1.8615 & 6.39 & $* * *$ & 1.7991 & 6.33 & $* * *$ \\
\hline$\beta_{\mathrm{C}}$ & -0.6314 & -2.59 & $* * *$ & -0.6989 & -2.66 & $* * *$ & -0.9780 & -3.61 & $* * *$ & -1.0304 & -3.88 & $* * *$ \\
\hline$\beta_{\mathrm{O}}$ & -0.5048 & -1.81 & * & -0.6410 & -2.16 & $* *$ & -0.3581 & -1.20 & & -0.4313 & -1.47 & \\
\hline$\beta_{\mathrm{V} \mathrm{V}}$ & 0.0401 & 1.80 & * & 0.0579 & 2.45 & $* *$ & 0.0302 & 1.25 & & 0.0463 & 1.96 & $* *$ \\
\hline$\beta_{\mathrm{V} \mathrm{C}}$ & -0.0139 & -0.77 & & -0.0059 & -0.31 & & -0.0041 & -0.21 & & -0.0147 & -0.77 & \\
\hline$\beta_{\mathrm{V} \mathrm{O}}$ & -0.0595 & -3.54 & $* * *$ & -0.0869 & -4.90 & $* * *$ & -0.0646 & -3.48 & $* * *$ & -0.0692 & -3.82 & \\
\hline$\beta_{\mathrm{C} \mathrm{C}}$ & 0.1213 & 6.19 & $* * *$ & 0.1221 & 5.88 & $* * *$ & 0.1352 & 6.39 & $* * *$ & 0.1441 & 6.89 & $* * *$ \\
\hline$\beta_{\mathrm{CO}}$ & -0.1174 & -7.16 & $* * *$ & -0.1306 & -7.50 & $* * *$ & -0.1445 & -8.21 & $* * *$ & -0.1390 & -8.01 & $* * *$ \\
\hline$\beta_{\mathrm{O} O}$ & 0.1830 & 7.28 & $* * *$ & 0.2376 & 9.00 & $* * *$ & 0.2313 & 8.58 & $* * *$ & 0.2284 & 8.54 & $* * *$ \\
\hline$\gamma_{\mathrm{RD}}$ & -0.4867 & -1.16 & & -0.5864 & -1.29 & & -0.5960 & -1.36 & & -0.7470 & -1.71 & \\
\hline$\gamma_{\mathrm{RD} \mathrm{RD}}$ & -0.0103 & -0.50 & & -0.0085 & -0.38 & & -0.0019 & -0.09 & & -0.0017 & -0.08 & \\
\hline$\alpha_{\mathrm{AA}}$ & 0.0487 & 17.96 & $* * *$ & 0.0517 & 19.02 & $* * *$ & 0.0496 & 18.20 & $* * *$ & 0.0497 & 18.21 & $* * *$ \\
\hline$\alpha_{\mathrm{AM}}$ & -0.0350 & -10.57 & $* * *$ & -0.0322 & -9.85 & $* * *$ & -0.0343 & -10.51 & $* * *$ & -0.0340 & -10.42 & $* * *$ \\
\hline$\alpha_{\mathrm{A} \mathrm{K}}$ & -0.0029 & -1.61 & & -0.0044 & -2.45 & $* *$ & -0.0029 & -1.62 & & -0.0030 & -1.65 & * \\
\hline$\alpha_{\mathrm{AL}}$ & -0.0108 & -4.87 & $* * *$ & -0.0151 & -6.91 & $* * *$ & -0.0125 & -6.01 & $* * *$ & -0.0128 & -6.16 & $* * *$ \\
\hline$\alpha_{\mathrm{MM}}$ & 0.1607 & 21.39 & $* * *$ & 0.1675 & 22.98 & $* * *$ & 0.1627 & 23.40 & $* * *$ & 0.1679 & 23.90 & $* * *$ \\
\hline$\alpha_{\mathrm{M} \mathrm{K}}$ & -0.0760 & -14.89 & $* * *$ & -0.0793 & -15.76 & $* * *$ & -0.0744 & -15.55 & $* * *$ & -0.0780 & -15.98 & $* * *$ \\
\hline$\alpha_{\mathrm{ML}}$ & -0.0498 & -11.77 & $* * *$ & -0.0561 & -13.79 & $* * *$ & -0.0541 & -14.26 & $* * *$ & -0.0559 & -14.72 & $* * *$ \\
\hline$\alpha_{\mathrm{K} \mathrm{K}}$ & 0.1353 & 24.60 & $* * *$ & 0.1364 & 24.96 & $* * *$ & 0.1325 & 25.04 & $* * *$ & 0.1350 & 25.08 & $* * *$ \\
\hline$\alpha_{\mathrm{K} \mathrm{L}}$ & -0.0563 & -28.77 & $* * *$ & -0.0527 & -27.92 & $* * *$ & -0.0552 & -31.90 & $* * *$ & -0.0541 & -30.62 & $* * *$ \\
\hline$\alpha_{\mathrm{LL}}$ & 0.1169 & 31.58 & $* * *$ & 0.1238 & 34.62 & $* * *$ & 0.1217 & 37.01 & $* * *$ & 0.1228 & 37.38 & $* * *$ \\
\hline$\delta_{\mathrm{AV}}$ & -0.0294 & -15.17 & $* * *$ & -0.0297 & -14.64 & $* * *$ & -0.0286 & -14.37 & $* * *$ & -0.0278 & -13.81 & $* * *$ \\
\hline$\delta_{\mathrm{AC}}$ & 0.0119 & 5.29 & $* * *$ & 0.0151 & 6.80 & $* * *$ & 0.0141 & 6.25 & $* * *$ & 0.0124 & 5.41 & $* * *$ \\
\hline$\delta_{\mathrm{AO}}$ & 0.0032 & 1.35 & & 0.0018 & 0.78 & & 0.0027 & 1.16 & & 0.0033 & 1.41 & \\
\hline$\delta_{\mathrm{M} \mathrm{V}}$ & 0.0713 & 19.37 & $* * *$ & 0.0681 & 17.51 & $* * *$ & 0.0667 & 18.54 & $* * *$ & 0.0643 & 17.30 & $* * *$ \\
\hline$\delta_{\mathrm{M} \mathrm{C}}$ & -0.0675 & -16.92 & $* * *$ & -0.0664 & -16.66 & $* * *$ & -0.0585 & -15.25 & $* * *$ & -0.0594 & -15.05 & $* * *$ \\
\hline$\delta_{\mathrm{M} \mathrm{O}}$ & 0.0395 & 9.25 & $* * *$ & 0.0386 & 8.99 & $* * *$ & 0.0316 & 7.61 & $* * *$ & 0.0354 & 8.44 & $* * *$ \\
\hline$\delta_{\mathrm{K} \mathrm{V}}$ & -0.0093 & -6.90 & $* * *$ & -0.0079 & -5.60 & $* * *$ & -0.0076 & -5.94 & $* * *$ & -0.0071 & -5.20 & $* * *$ \\
\hline$\delta_{\mathrm{K} \mathrm{C}}$ & 0.0214 & 13.49 & $* * *$ & 0.0203 & 13.15 & $* * *$ & 0.0164 & 10.84 & $* * *$ & 0.0180 & 11.36 & $* * *$ \\
\hline$\delta_{\mathrm{K} \mathrm{O}}$ & -0.0273 & -15.99 & $* * *$ & -0.0271 & -16.00 & $* * *$ & -0.0238 & -14.67 & $* * *$ & -0.0261 & -15.61 & $* * *$ \\
\hline$\delta_{\mathrm{LV}}$ & -0.0326 & -12.31 & $* * *$ & -0.0305 & -11.09 & $* * *$ & -0.0304 & -11.67 & $* * *$ & -0.0294 & -11.00 & $* * *$ \\
\hline$\delta_{\mathrm{L} \mathrm{C}}$ & 0.0343 & 11.77 & $* * *$ & 0.0309 & 10.85 & $* * *$ & 0.0281 & 9.98 & $* * *$ & 0.0290 & 10.07 & $* * *$ \\
\hline
\end{tabular}




\section{Continued}

\begin{tabular}{|c|c|c|c|c|c|c|c|c|c|c|c|c|}
\hline$\delta_{\mathrm{LO}}$ & -0.0154 & -4.87 & $* * *$ & -0.0133 & -4.25 & $* * *$ & -0.0105 & -3.38 & $* * *$ & -0.0126 & -4.03 & $* * *$ \\
\hline$\theta_{\mathrm{ARD}}$ & -0.0165 & -6.06 & $* * *$ & -0.0205 & -7.98 & $* * *$ & -0.0193 & -7.61 & $* * *$ & -0.0199 & -7.84 & $* * *$ \\
\hline$\theta_{\mathrm{M} \mathrm{RD}}$ & -0.0044 & -0.94 & & -0.0010 & -0.22 & & -0.0045 & -1.04 & & 0.0000 & 0.01 & \\
\hline$\theta_{\mathrm{K} \mathrm{RD}}$ & -0.0129 & -6.88 & $* * *$ & -0.0131 & -7.41 & $* * *$ & -0.0122 & -7.25 & $* * *$ & -0.0140 & -8.04 & $* * *$ \\
\hline$\theta_{\mathrm{L} \mathrm{RD}}$ & 0.0338 & 9.58 & $* * *$ & 0.0346 & 10.32 & $* * *$ & 0.0360 & 10.90 & $* * *$ & 0.0339 & 10.18 & $* * *$ \\
\hline$\varphi_{\mathrm{V} \mathrm{RD}}$ & -0.0416 & -2.73 & $* * *$ & -0.0574 & -3.56 & $* * *$ & -0.0586 & -3.58 & $* * *$ & -0.0557 & -3.46 & $* * *$ \\
\hline$\varphi_{\mathrm{C} \text { RD }}$ & 0.0498 & 3.70 & $* * *$ & 0.0560 & 3.80 & $* * *$ & 0.0683 & 4.62 & $* * *$ & 0.0690 & 4.79 & $* * *$ \\
\hline$\varphi_{\mathrm{O} \mathrm{RD}}$ & 0.0453 & 2.95 & $* * *$ & 0.0484 & 2.98 & $* * *$ & 0.0311 & 1.89 & * & 0.0360 & 2.21 & $* *$ \\
\hline$\xi_{\mathrm{ET} \mathrm{RD}}$ & -0.0154 & -18.82 & $* * *$ & -0.0144 & -16.48 & $* * *$ & -0.0149 & -17.65 & $* * *$ & -0.0150 & -17.49 & $* * *$ \\
\hline$\xi_{\text {RO RD }}$ & -0.0021 & -4.38 & $* * *$ & -0.0031 & -5.83 & $* * *$ & -0.0035 & -7.27 & $* * *$ & -0.0033 & -6.85 & $* * *$ \\
\hline$\xi_{\mathrm{SR} \mathrm{RD}}$ & -0.0091 & -12.45 & $* * *$ & -0.0010 & -1.12 & & -0.0037 & -9.46 & $* * *$ & -0.0026 & -8.42 & $* * *$ \\
\hline$\rho_{\mathrm{ET} \mathrm{A}}$ & -0.0106 & -4.11 & $* * *$ & -0.0101 & -3.82 & $* * *$ & -0.0104 & -3.95 & $* * *$ & -0.0094 & -3.62 & $* * *$ \\
\hline$\rho_{\mathrm{RO} \mathrm{A}}$ & -0.0063 & -3.71 & $* * *$ & -0.0092 & -5.21 & $* * *$ & -0.0083 & -4.85 & $* * *$ & -0.0077 & -4.55 & $* * *$ \\
\hline$\rho_{\mathrm{SR} \mathrm{A}}$ & -0.0159 & -3.45 & $* * *$ & 0.0110 & 3.08 & $* * *$ & -0.0013 & -1.13 & & -0.0028 & -3.02 & $* * *$ \\
\hline$\rho_{\mathrm{ET} \mathrm{M}}$ & 0.0636 & 13.04 & $* * *$ & 0.0582 & 11.87 & $* * *$ & 0.0570 & 12.15 & $* * *$ & 0.0593 & 12.45 & $* * *$ \\
\hline$\rho_{\mathrm{RO} M}$ & 0.0096 & 3.15 & $* * *$ & 0.0119 & 3.76 & $* * *$ & 0.0114 & 3.91 & $* * *$ & 0.0118 & 4.01 & $* * *$ \\
\hline$\rho_{\mathrm{SR} \mathrm{M}}$ & 0.0112 & 1.52 & & 0.0029 & 0.48 & & 0.0202 & 9.57 & $* * *$ & 0.0133 & 7.83 & $* * *$ \\
\hline$\rho_{\mathrm{ET} \mathrm{K}}$ & -0.0210 & -11.50 & $* * *$ & -0.0198 & -10.91 & $* * *$ & -0.0180 & -10.53 & $* * *$ & -0.0199 & -11.24 & $* * *$ \\
\hline$\rho_{\mathrm{RO} \mathrm{K}}$ & -0.0056 & -4.72 & $* * *$ & -0.0052 & -4.35 & $* * *$ & -0.0049 & -4.50 & $* * *$ & -0.0057 & -5.04 & $* * *$ \\
\hline$\rho_{\mathrm{SR} \mathrm{K}}$ & -0.0006 & -0.17 & & -0.0058 & -2.33 & & -0.0086 & -11.57 & $* * *$ & -0.0043 & -7.03 & $* * *$ \\
\hline$\rho_{\mathrm{ET} \mathrm{L}}$ & -0.0320 & -9.04 & $* * *$ & -0.0284 & -8.14 & $* * *$ & -0.0287 & -8.34 & $* * *$ & -0.0300 & -8.66 & $* * *$ \\
\hline$\rho_{\mathrm{RO} \mathrm{L}}$ & 0.0023 & 1.04 & & 0.0025 & 1.09 & & 0.0018 & 0.85 & & 0.0016 & 0.75 & \\
\hline$\rho_{\mathrm{SR} \mathrm{L}}$ & 0.0051 & 0.87 & & -0.0081 & -1.77 & * & -0.0103 & -6.79 & $* * *$ & -0.0062 & -5.12 & $* * *$ \\
\hline$\rho_{\mathrm{W} \mathrm{A}}$ & -0.0002 & -0.39 & & -0.0005 & -0.99 & & -0.0002 & -0.48 & & -0.0002 & -0.46 & \\
\hline$\rho_{\mathrm{WM}}$ & 0.0007 & 1.05 & & 0.0004 & 0.67 & & 0.0004 & 0.57 & & 0.0003 & 0.51 & \\
\hline$\rho_{\mathrm{W} \mathrm{K}}$ & -0.0014 & -4.24 & $* * *$ & -0.0012 & -3.73 & $* * *$ & -0.0013 & -4.12 & $* * *$ & -0.0013 & -3.93 & $* * *$ \\
\hline$\rho_{\mathrm{W} \mathrm{L}}$ & 0.0009 & 1.55 & & 0.0012 & 2.21 & $* *$ & 0.0011 & 2.03 & * & 0.0011 & 2.05 & $* *$ \\
\hline equations & $\mathrm{R}^{2}$ & $\begin{array}{c}\text { adjusted } \\
\mathrm{R}^{2}\end{array}$ & & $\mathrm{R}^{2}$ & $\begin{array}{c}\text { adjusted } \\
\mathrm{R}^{2}\end{array}$ & & $\mathrm{R}^{2}$ & $\begin{array}{c}\text { adjusted } \\
\mathrm{R}^{2}\end{array}$ & & $\mathrm{R}^{2}$ & adjusted $\mathrm{R}^{2}$ & \\
\hline LnTVC & 0.9811 & 0.98 & & 0.9779 & 0.98 & & 0.9795 & 0.98 & & 0.9789 & 0.98 & \\
\hline$S_{M}$ & 0.4856 & 0.48 & & 0.4719 & 0.47 & & 0.5240 & 0.52 & & 0.5026 & 0.50 & \\
\hline $\mathrm{S}_{\mathrm{K}}$ & 0.7396 & 0.74 & & 0.7405 & 0.74 & & 0.7737 & 0.77 & & 0.7513 & 0.75 & \\
\hline $\mathrm{S}_{\mathrm{L}}$ & 0.6642 & 0.66 & & 0.6711 & 0.67 & & 0.6838 & 0.68 & & 0.6740 & 0.67 & \\
\hline
\end{tabular}

Note 1: The spillin $\mathrm{RD}$ stocks are based on production region, geographical distance, un-weighted production profile, and correlation weighted production cluster for Model 1 to Model 4, respectively. Note 2: $\mathrm{V}$ stands for livestock, $\mathrm{C}$ for crops, $\mathrm{O}$ for other farm related goods and services, A for land, L for labor, $\mathrm{M}$ for materials, $\mathrm{K}$ for capital, RD for own agricultural R\&D stock, ET for extension, RO for road density, SR for R \& D spillins. Note 3 : ${ }^{* * * i n d i c a t e s ~ s i g n i f i-~}$ cant at $1 \%$ level. ${ }^{* *}$ indicates significant at $5 \%$ level. ${ }^{*}$ indicates significant at $10 \%$ level. 
Table 6. Cost Elasticity of R \& D, Extension Services (ET), Roads (RO), and Spill-in R \& D Stocks (SR), 48 States, US Agriculture, 1980-2004, alternative spill-in models.

\begin{tabular}{cccccccccc}
\hline \multirow{2}{*}{ Elasticity } & Frequencies & \multicolumn{2}{c}{ Model 1 } & \multicolumn{2}{c}{ Model 2 } & \multicolumn{2}{c}{ Model 3 } & \multicolumn{2}{c}{ Model 4 } \\
\cline { 3 - 10 } & & mean & standard deviation & mean & standard deviation & mean & standard deviation & mean & standard deviation \\
\hline$\xi_{\mathrm{RD}}$ & 1200 & -0.1287 & 0.0903 & -0.1518 & 0.0860 & -0.1347 & 0.0808 & -0.1511 & 0.0889 \\
$\xi_{\mathrm{ET}}$ & 1200 & -0.2482 & 0.0209 & -0.2329 & 0.0191 & -0.2419 & 0.0193 & -0.2428 & 0.0197 \\
$\xi_{\mathrm{RO}}$ & 1200 & -0.0361 & 0.0038 & -0.0538 & 0.0054 & -0.0608 & 0.0051 & -0.0579 & 0.0049 \\
$\xi_{\mathrm{SRD}}$ & 1200 & -0.1637 & 0.0103 & -0.0142 & 0.0064 & -0.0576 & 0.0061 & -0.0402 & 0.0041 \\
\hline
\end{tabular}

Note: The spillin RD stocks are based on production region, geographical distance, un-weighted production profile, and correlation weighted production cluster for Model 1 to Model 4, respectively.

Table 7. Marginal Effect of the Extension Service, Roads and R \& D spill-ins on R \& D's Cost Saving, 48 States, US Agriculture, 1980-2004, alternative Spill-in models.

\begin{tabular}{ccccccccc}
\hline \multirow{2}{*}{ Marginal effect } & \multicolumn{2}{c}{ Model 1 } & \multicolumn{2}{c}{ Model 2 } & \multicolumn{2}{c}{ Model 3 } & \multicolumn{2}{c}{ Model4 } \\
\cline { 2 - 8 } & value & t ratio & value & t ratio & value & t ratio & value & t ratio \\
\hline ME $_{\text {RDET }}$ & -0.015 & -18.82 & -0.014 & -16.48 & -0.015 & -17.65 & -0.015 & -17.49 \\
ME $_{\text {RDRO }}$ & -0.002 & -4.38 & -0.003 & -5.83 & -0.004 & -7.27 & -0.003 & -6.85 \\
ME $_{\text {RDSR }}$ & -0.009 & -12.45 & -0.001 & -1.12 & -0.004 & -9.46 & -0.003 & -8.42 \\
\hline
\end{tabular}

Note: The spillin RD stocks are based on production region, geographical distance, un-weighted production profile, and correlation weighted production cluster for Model 1 to Model 4, respectively.

and R \& D spill-ins significantly enhance the cost-reducing effect of local R \& D expenditures. Among the efficiency variables, extension activities have the greatest impact while road density has the smallest impact. This effect, paired with the decreasing trend of the extension variable through time, is important in understanding the evolution of the own-state internal rate of return, as will be seen later.

The results presented in Table 6 and Table 7 provide evidence that own R \& $\mathrm{D}$, as well as $\mathrm{R} \& \mathrm{D}$ spill-ins, extension activities, and road density, have a positive and significant effect on the productivity of US agriculture (except R \& D spill-ins from Model 2). It also shows that the estimated impacts of $R \& D$ spill-ins on productivity vary across models with Model 1, based on the USDA production regions, having the largest impact and Model 2, based on geographical distances, having the smallest. This finding is consistent with [14] even when using a different data set and procedure.

Next, we use the estimated coefficients and Equations (13) and (17) to calculate own and social rates of return to agricultural research by state and by year. The annual rates of return for all states by year are shown in Table 8. Note that own-state rates of return $\left(r_{1}\right)$ are robust across the different model specifications. Note also the sensitivity of the estimated social rates of return to alternative proxies for research spill-ins. Estimates from Models 3 and 4 that use the "production mix" approach to the construction of the R \& D spill-in stocks are very close while those from Model 1 and 2, based on geographical proximity are very different. The rates in Model 1, estimated using the most common approach 
found in the literature (i.e., grouping states according to the USDA production regions) are the largest, while those from Model 2 are the smallest. This is consistent with the relative magnitude of the spill-in R \& D stocks calculated across these models (see Table 3 and Figure 1). Alston et al. [14] using a different approach and data set also found larger internal rates of return when using the geographical proximity rather than the production mix approach.

Figure 4 and Figure 5 show the evolution of the internal rates of return. We

Table 8. Internal Rate of Return of Public R \& D in Agriculture by Year, 48 US States, 1980-2004, alternative Spill-in models.

\begin{tabular}{|c|c|c|c|c|c|c|c|c|c|c|c|c|c|c|c|c|}
\hline \multirow{3}{*}{ Year } & \multicolumn{4}{|c|}{ Model 1} & \multicolumn{4}{|c|}{ Model 2} & \multicolumn{4}{|c|}{ Model 3} & \multicolumn{4}{|c|}{ Model 4} \\
\hline & & $\mathrm{r}_{1}$ & & $\mathrm{r}_{2}$ & & $\mathrm{r}_{1}$ & & $\mathrm{r}_{2}$ & & $\mathrm{r}_{1}$ & & $\mathrm{r}_{2}$ & & $\mathrm{r}_{1}$ & & $\mathrm{r}_{2}$ \\
\hline & mean & $\begin{array}{l}\text { standard } \\
\text { deviation }\end{array}$ & mean & $\begin{array}{l}\text { standard } \\
\text { deviation }\end{array}$ & mean & $\begin{array}{l}\text { standard } \\
\text { deviation }\end{array}$ & mean & $\begin{array}{l}\text { standard } \\
\text { deviation }\end{array}$ & mean & $\begin{array}{l}\text { standard } \\
\text { deviation }\end{array}$ & mean & $\begin{array}{c}\text { standard } \\
\text { deviation }\end{array}$ & mean & $\begin{array}{l}\text { standard } \\
\text { deviation }\end{array}$ & mean & $\begin{array}{l}\text { standard } \\
\text { deviation }\end{array}$ \\
\hline 1980 & 13.89 & 11.02 & 39.26 & 19.49 & 15.90 & 12.85 & 16.43 & 12.77 & 14.31 & 12.37 & 25.96 & 15.46 & 15.48 & 12.60 & 28.11 & 21.72 \\
\hline 1981 & 16.01 & 11.65 & 43.36 & 21.02 & 18.11 & 13.51 & 18.58 & 13.43 & 16.12 & 12.82 & 29.11 & 16.80 & 17.42 & 13.12 & 31.63 & 23.94 \\
\hline 1982 & 13.87 & 8.45 & 42.56 & 19.51 & 16.56 & 10.70 & 17.01 & 10.65 & 14.96 & 10.86 & 28.60 & 15.54 & 16.20 & 10.95 & 30.91 & 23.88 \\
\hline 1983 & 15.05 & 9.11 & 42.23 & 18.90 & 17.35 & 11.18 & 17.74 & 11.13 & 16.22 & 11.48 & 28.69 & 15.49 & 17.30 & 11.57 & 31.36 & 23.66 \\
\hline 1984 & 14.95 & 9.19 & 43.08 & 19.37 & 17.30 & 11.45 & 17.11 & 11.93 & 15.57 & 11.63 & 29.31 & 15.93 & 16.69 & 11.82 & 31.85 & 24.59 \\
\hline 1985 & 13.02 & 7.67 & 41.29 & 18.47 & 15.74 & 9.98 & 16.19 & 9.99 & 14.34 & 10.31 & 28.20 & 15.19 & 15.51 & 10.35 & 30.42 & 23.98 \\
\hline 1986 & 10.95 & 7.08 & 38.03 & 17.19 & 13.77 & 9.19 & 14.38 & 9.17 & 12.31 & 9.87 & 26.11 & 14.31 & 13.59 & 9.74 & 28.25 & 22.75 \\
\hline 1987 & 10.53 & 7.07 & 36.87 & 16.53 & 13.01 & 9.35 & 13.65 & 9.33 & 11.67 & 10.01 & 25.36 & 14.07 & 12.93 & 9.84 & 27.41 & 22.59 \\
\hline 1988 & 10.59 & 7.22 & 37.51 & 16.58 & 13.33 & 9.46 & 13.53 & 9.89 & 12.56 & 10.15 & 25.91 & 14.21 & 13.52 & 10.15 & 28.07 & 22.38 \\
\hline 1989 & 10.19 & 7.50 & 37.76 & 16.94 & 12.71 & 9.43 & 13.51 & 9.39 & 11.62 & 10.34 & 25.95 & 14.44 & 12.82 & 10.11 & 27.73 & 22.78 \\
\hline 1990 & 10.07 & 6.85 & 38.14 & 17.13 & 12.82 & 9.10 & 13.67 & 9.09 & 11.64 & 9.80 & 26.44 & 14.59 & 12.76 & 9.74 & 28.24 & 23.74 \\
\hline 1991 & 9.75 & 6.69 & 37.23 & 16.73 & 12.42 & 8.85 & 13.22 & 8.86 & 11.48 & 9.62 & 25.73 & 14.36 & 12.49 & 9.59 & 27.63 & 23.51 \\
\hline 1992 & 9.77 & 6.91 & 37.38 & 17.10 & 12.42 & 8.98 & 13.25 & 9.01 & 11.14 & 9.52 & 25.80 & 14.58 & 12.23 & 9.49 & 27.52 & 24.02 \\
\hline 1993 & 10.07 & 7.01 & 37.56 & 16.67 & 12.73 & 9.03 & 13.60 & 9.01 & 11.60 & 9.73 & 26.31 & 14.62 & 12.69 & 9.65 & 28.75 & 24.98 \\
\hline 1994 & 9.23 & 6.42 & 38.40 & 17.25 & 12.57 & 8.73 & 13.51 & 8.74 & 11.09 & 9.42 & 26.88 & 14.91 & 12.30 & 9.38 & 29.26 & 25.75 \\
\hline 1995 & 9.66 & 6.84 & 38.23 & 16.81 & 12.72 & 9.17 & 13.64 & 9.13 & 11.71 & 10.09 & 26.96 & 14.95 & 12.80 & 10.01 & 28.92 & 25.61 \\
\hline 1996 & 9.92 & 7.55 & 39.43 & 17.15 & 13.15 & 9.51 & 14.12 & 9.42 & 11.65 & 10.25 & 27.74 & 15.10 & 12.91 & 10.11 & 29.75 & 26.86 \\
\hline 1997 & 9.30 & 6.77 & 39.70 & 17.20 & 12.77 & 8.68 & 13.77 & 8.64 & 11.38 & 9.63 & 27.86 & 14.81 & 12.61 & 9.41 & 30.54 & 26.65 \\
\hline 1998 & 7.95 & 7.44 & 39.31 & 17.24 & 11.37 & 7.87 & 12.58 & 7.79 & 10.31 & 9.08 & 28.00 & 15.14 & 11.34 & 8.95 & 30.59 & 28.00 \\
\hline 1999 & 8.27 & 6.37 & 39.15 & 17.04 & 11.37 & 7.79 & 12.43 & 7.77 & 10.41 & 9.11 & 28.04 & 14.93 & 11.64 & 8.78 & 30.51 & 27.37 \\
\hline 2000 & 8.78 & 6.87 & 40.32 & 17.35 & 12.65 & 8.79 & 13.64 & 8.76 & 11.47 & 10.20 & 28.96 & 15.27 & 12.74 & 9.87 & 31.23 & 27.71 \\
\hline 2001 & 8.35 & 7.50 & 40.39 & 17.34 & 12.42 & 8.29 & 13.46 & 8.26 & 11.62 & 9.44 & 29.01 & 15.01 & 12.40 & 9.56 & 31.72 & 28.07 \\
\hline 2002 & 9.03 & 6.91 & 40.28 & 17.23 & 12.78 & 8.94 & 13.90 & 8.86 & 11.98 & 9.92 & 29.14 & 15.18 & 12.73 & 10.15 & 32.30 & 29.08 \\
\hline 2003 & 9.55 & 6.71 & 40.69 & 17.51 & 12.21 & 8.95 & 13.46 & 8.74 & 11.17 & 10.07 & 29.18 & 15.49 & 12.65 & 9.50 & 32.16 & 29.30 \\
\hline 2004 & 8.55 & 6.60 & 40.77 & 17.89 & 11.53 & 7.39 & 12.37 & 8.05 & 9.91 & 8.81 & 29.23 & 15.63 & 11.48 & 8.22 & 31.47 & 28.85 \\
\hline
\end{tabular}

Note 1: The spillin RD stocks are based on production region, geographical distance, un-weighted production profile, and correlation weighted production cluster for Model 1 to Model 4, respectively. Note 2: $r_{1}$ indicates local internal rate of return, and $r_{2}$ indicates social internal rate of return. 


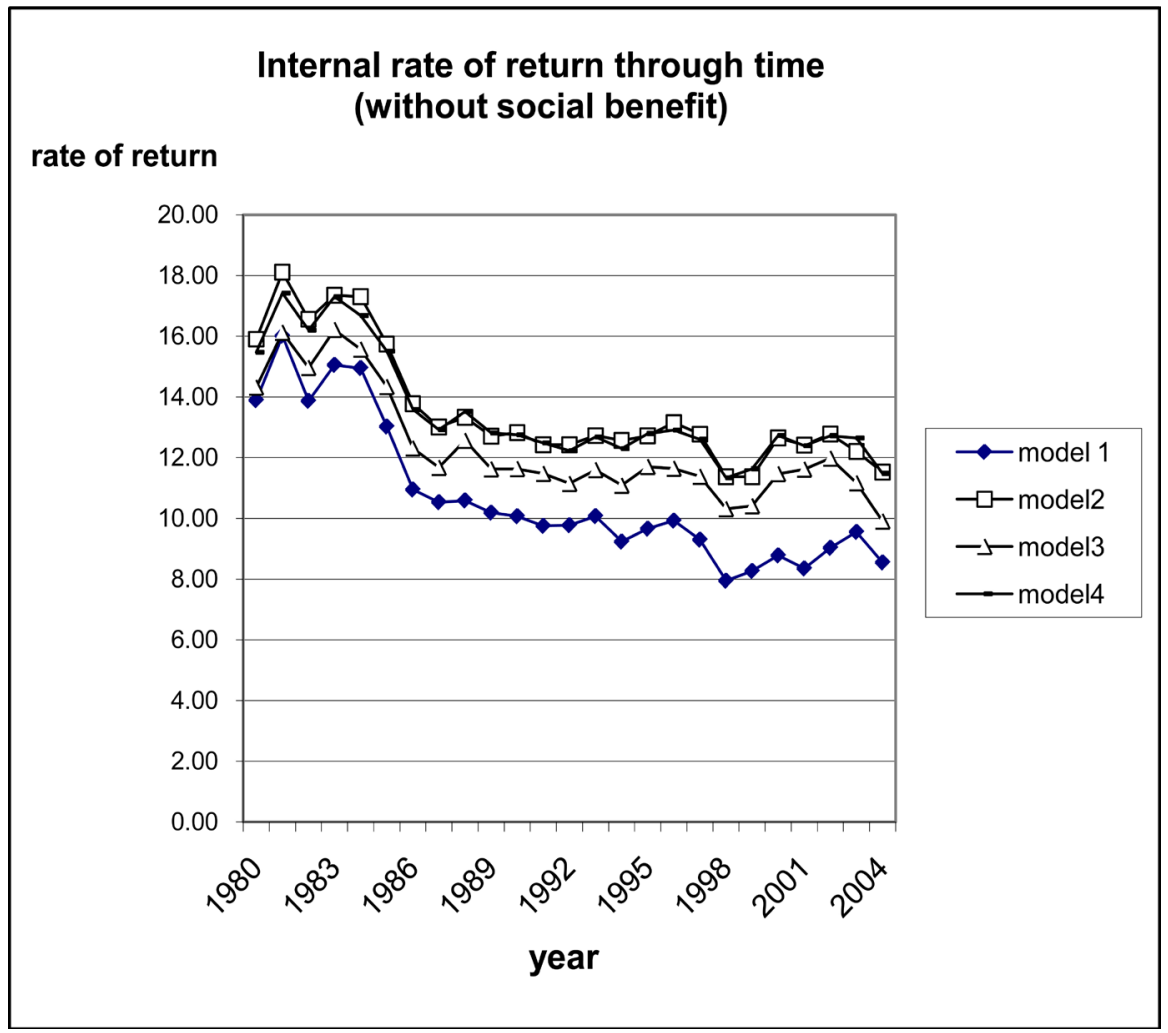

Figure 4. Own internal rate of return, US agriculture, 1980-2004, alternative spill-in models (without social benefit).

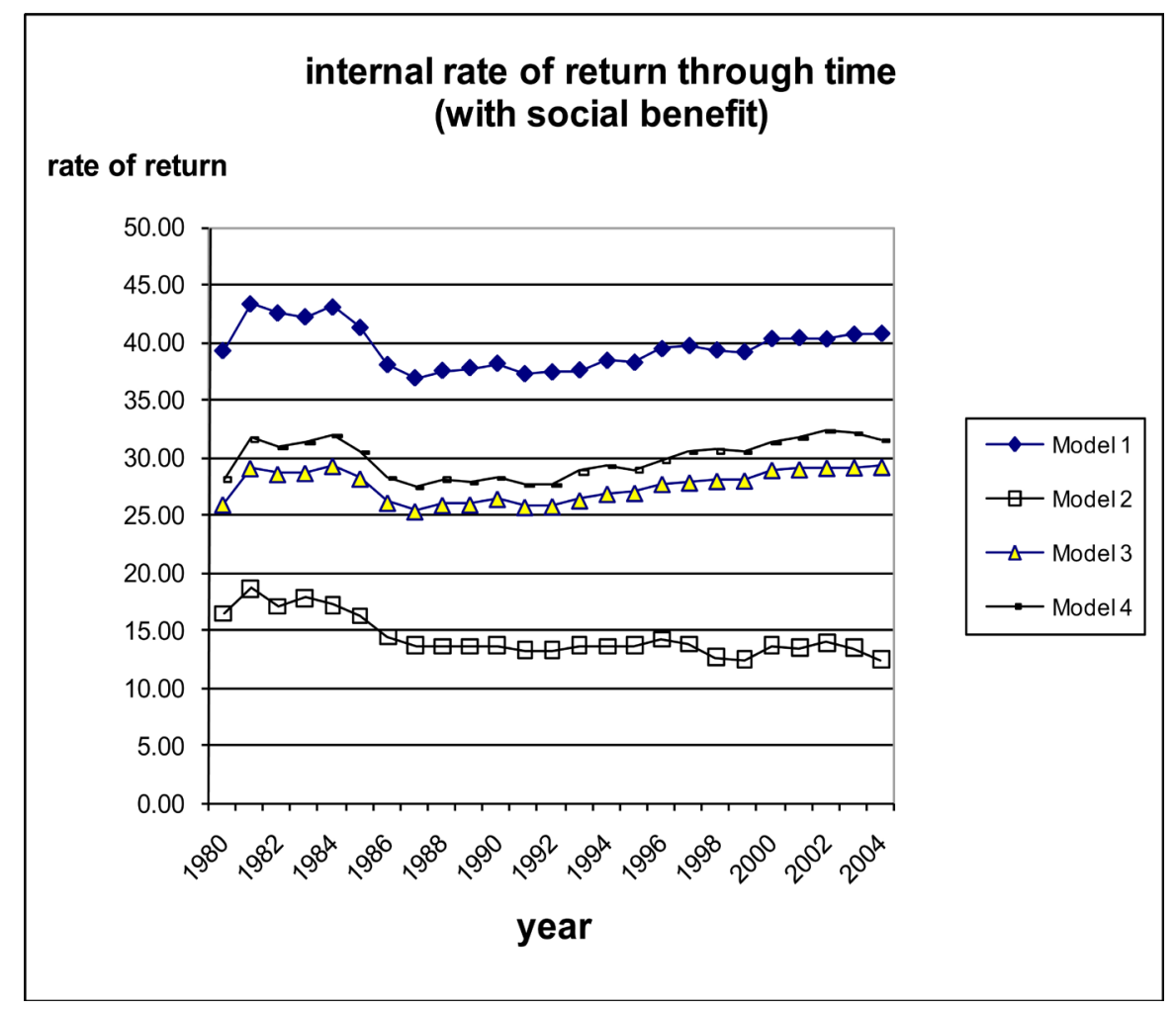

Figure 5. Social internal rate of return, US agriculture, 1980-2004, alternative spill-in models (with social benefit). 
see that both the own-state internal rate of return $r_{1}$ and the social rate of return $r_{2}$ in all four models declined beginning in the mid-1980s. While the own-state internal rates of return $\left(r_{1}\right)$ continued to decline over the sample period, the social internal rates of return $\left(r_{2}\right)$ stabilized or exhibited a slight increase. The declining own-state internal rates of return estimated here are associated with declining extension staffing during these years. However, in the estimation of the social rates of return, this effect seems to be outweighed by research spill-ins. The average local rate of return across models ranged from 10.69\% in Model 1 to $13.49 \%$ in Model 4 . The average social rate of return ranged from $14.35 \%$ in Model 2 to $39.56 \%$ in Model 1. These IRR rates are lower than the ones in [15] and $[16]^{12}$.

Table 9 reports the rates of return by production region. The estimates of local rates of return are robust to the model specification. Estimates of the social rates of return across the regions are much lower for Model 2 than for the other three models. The rates of return for the Lake States, Corn Belt, Appalachia, Delta, Southern Plains, and Pacific regions are less dispersed than the rates for the Northeast region. The Lake States, Corn Belt, Northern Plains, and Southern Plains regions have both higher local and social rates of return.

Based on the estimated marginal effects (Equation (8)) of extension activities, road density, and $\mathrm{R} \& \mathrm{D}$ spill-ins, we calculate the impacts of these variables on the internal rates of return (Equations (12)-(17)). These results are presented in Table 10. A 10 percent increase in extension activities increases the local internal rate of return, on average, by approximately 1.44 percent. If, for example, the local internal rate of return on investments in $\mathrm{R} \& \mathrm{D}$ is 12 percent, a 10 percent increase in extension services increases this rate to 13.44 percent. This boosts the social rates of return from an average of 0.36 percentage points in Model 1 to 1.18 percentage points in Model 2. We note, however, that the extension variable shows a decreasing trend during the period of analysis. Research spill-ins also have an important positive effect on social rates, ranking second in magnitude to investments in extension activities. Contrary to the evolution of the extension variable, the spill-in stock variables have all trended up over the sample period.

\section{Summary and Conclusions}

This paper uses data for a panel of states developed by USDA to estimate the own and social internal rates of return to public R \& D expenditures in agriculture. The social rates of return incorporate the interaction with $\mathrm{R} \& \mathrm{D}$ spill-ins from other states, extension activities, and road density. We construct four alternative measures of potential R \& D spill-ins based on geographic proximity

\footnotetext{
${ }^{12}[16]$ uses the same USDA data set, an updated R \& D stock variable, construct spill-ins using the geographical proximity approach (our Model 1), use a different proxy for Extension, do not include roads and use a two-step approach regressing the USDA productivity index on research and extension variables. [14] uses the same two-step procedure but the productivity index and the research and extension stocks are obtained using a different data set and different functional specifications. They use the production profile approach (our Model 3) to obtain spill-in stocks. Note that they calculate an internal rate of return and a modified internal rate of return.
} 
Table 9. Internal Rate of Return by Region, US Agriculture, 1980-2004, alternative Spill-in models.

\begin{tabular}{|c|c|c|c|c|c|c|c|c|c|c|c|c|c|c|c|c|}
\hline \multirow{2}{*}{ Region } & \multicolumn{4}{|c|}{ Model 1} & \multicolumn{4}{|c|}{ Model 2} & \multicolumn{4}{|c|}{ Model 3} & \multicolumn{4}{|c|}{ Model 4} \\
\hline & $\mathrm{r} 1$ & & $\mathrm{r} 2$ & & $\mathrm{r} 1$ & & $\mathrm{r} 2$ & & r1 & & $\mathrm{r} 2$ & & r1 & & $\mathrm{r} 2$ & \\
\hline 1. Northeast & 9.88 & 10.06 & 31.14 & 19.85 & 10.98 & 11.28 & 11.43 & 11.42 & 10.13 & 11.23 & 19.57 & 20.02 & 11.18 & 11.38 & 29.98 & 30.56 \\
\hline 2. Lake States & 11.35 & 5.30 & 51.09 & 8.54 & 15.02 & 4.15 & 15.86 & 3.90 & 12.59 & 4.74 & 35.34 & 4.31 & 13.72 & 4.40 & 25.25 & 5.43 \\
\hline 3. Corn Belt & 13.05 & 6.00 & 55.22 & 11.47 & 16.58 & 6.57 & 17.19 & 6.74 & 13.31 & 6.20 & 36.94 & 8.25 & 14.26 & 6.65 & 28.55 & 6.59 \\
\hline 4. North Plains & 16.16 & 13.86 & 52.95 & 16.11 & 24.70 & 16.70 & 25.92 & 16.04 & 23.62 & 19.44 & 38.84 & 15.22 & 25.82 & 18.84 & 38.03 & 15.42 \\
\hline 5. Appalachian & 11.62 & 5.55 & 26.09 & 9.73 & 14.10 & 6.55 & 14.38 & 6.58 & 13.03 & 6.38 & 26.90 & 10.33 & 14.09 & 6.44 & 43.02 & 45.81 \\
\hline 6. Southeast & 7.32 & 5.14 & 34.69 & 9.43 & 9.65 & 4.04 & 10.15 & 3.72 & 8.22 & 5.44 & 25.05 & 5.91 & 9.40 & 4.28 & 16.91 & 3.91 \\
\hline 7. Delta States & 7.62 & 3.34 & 34.87 & 5.86 & 9.19 & 4.18 & 9.53 & 4.17 & 8.42 & 4.20 & 24.18 & 7.82 & 9.22 & 4.07 & 23.38 & 4.31 \\
\hline 8. Southern Plains & 20.76 & 6.64 & 54.53 & 18.42 & 27.26 & 4.77 & 27.63 & 4.59 & 29.51 & 4.69 & 47.44 & 9.97 & 29.82 & 4.54 & 32.25 & 4.76 \\
\hline 9. Mountain & 9.31 & 5.17 & 40.14 & 14.30 & 10.72 & 5.92 & 12.58 & 5.79 & 9.78 & 6.09 & 20.53 & 8.74 & 10.99 & 6.00 & 31.98 & 26.52 \\
\hline 10. Pacific & 9.27 & 3.23 & 36.99 & 16.45 & 11.67 & 3.88 & 11.98 & 5.53 & 8.97 & 4.09 & 31.40 & 9.37 & 10.74 & 4.02 & 18.28 & 4.98 \\
\hline
\end{tabular}

Note 1: The spillin RD stocks are based on production region, geographical distance, un-weighted production profile, and correlation weighted production cluster for Model 1 to Model 4, respectively. Note 2: $r_{1}$ indicates local internal rate of return, and $r_{2}$ indicates social internal rate of return.

Table 10. Impacts of the Extension Service, Roads, and Spill-in R \& D on Internal Rate of Return in US Agriculture, 1980-2004, alternative Spill-in models.

\begin{tabular}{|c|c|c|c|c|c|c|c|c|c|c|c|c|c|c|c|c|}
\hline & \multicolumn{4}{|c|}{ Model 1} & \multicolumn{4}{|c|}{ Model 2} & \multicolumn{4}{|c|}{ Model 3} & \multicolumn{4}{|c|}{ Model 4} \\
\hline & $\mathrm{r} 1$ & & $\mathrm{r} 2$ & & $\mathrm{r} 1$ & & $\mathrm{r} 2$ & & $\mathrm{r} 1$ & & $\mathrm{r} 2$ & & $\mathrm{r} 1$ & & $\mathrm{r} 2$ & \\
\hline internal rate of return & 10.75 & 7.98 & 39.56 & 17.62 & 13.61 & 9.71 & 16.96 & 10.32 & 12.36 & 10.29 & 27.54 & 14.96 & 13.52 & 10.23 & 29.29 & 15.56 \\
\hline add $10 \%$ of ET & 12.15 & 8.35 & 39.92 & 17.55 & 15.06 & 10.15 & 18.17 & 10.67 & 13.79 & 10.77 & 28.21 & 15.09 & 15.01 & 10.72 & 30.01 & 15.64 \\
\hline contribution of ET & 1.40 & 0.38 & 0.36 & 0.43 & 1.44 & 0.44 & 1.18 & 0.59 & 1.43 & 0.48 & 0.67 & 0.57 & 1.49 & 0.49 & 0.72 & 0.61 \\
\hline add $10 \%$ of RO & 10.95 & 8.03 & 39.61 & 17.61 & 13.94 & 9.81 & 17.22 & 10.41 & 12.71 & 10.41 & 27.70 & 14.99 & 13.86 & 10.35 & 29.46 & 15.58 \\
\hline contribution of RO & 0.20 & 0.05 & 0.05 & 0.06 & 0.32 & 0.10 & 0.26 & 0.15 & 0.35 & 0.12 & 0.16 & 0.13 & 0.34 & 0.11 & 0.16 & 0.14 \\
\hline add $10 \%$ of SR & 11.60 & 8.20 & 39.77 & 17.58 & 13.72 & 9.74 & 17.04 & 10.35 & 12.73 & 10.42 & 27.71 & 14.99 & 13.78 & 10.32 & 29.42 & 15.57 \\
\hline contribution of SR & 0.84 & 0.23 & 0.22 & 0.26 & 0.10 & 0.03 & 0.08 & 0.05 & 0.37 & 0.12 & 0.17 & 0.14 & 0.27 & 0.09 & 0.13 & 0.11 \\
\hline
\end{tabular}

Note 1: The spillin RD stocks are based on production region, geographical distance, un-weighted production profile, and correlation weighted production cluster for Model 1 to Model 4, respectively. Note 2: $\mathrm{r}_{1}$ indicates local internal rate of return, and $\mathrm{r}_{2}$ indicates social internal rate of return.

and similarities in production to determine the sensitivity of the estimated rates of return to model specification. We estimate four models, using a different measure of potential R \& D spill-in in each model. Our estimates indicate that extension activities, road density, and R \& D spill-ins from other states play an important role in determining the efficacy of $\mathrm{R} \& \mathrm{D}$ expenditures. Among these variables, the impact of extension activities seems to be the strongest. These activities enhance productivity growth by facilitating dissemination of technical 
information.

We estimate own and social rates of return that, although high, are lower than the ones found in previous literature. Local internal rates are, on average across all years, states and models, 12 percent while social rates are 27 percent. The estimates of the own internal rates of return are robust across the alternative models, while the social internal rates of return deviate from each other depending on the particular measure of $\mathrm{R} \& \mathrm{D}$ spill-ins. The social rates of return based on USDA production regions are much higher than those estimated by the other models. This is important given the prevalence in the literature of the production mix approach for the calculation of knowledge spill-in stocks. We find that the decline in own rates is associated with declines in extension investments during this period. These findings can inform decisions about allocating public resources to alternative research and extension activities.

\section{References}

[1] Griliches, Z. (1958) Research Costs and Social Returns: Hybrid Corn and Related Innovations. Journal of Political Economy, 66, 419-431. https://doi.org/10.1086/258077

[2] Griliches, Z. (1964) Research Expenditures, Education and the Aggregate Agricultural Production Function. American Economic Review, 54, 961-974.

[3] Evenson, R.E. (1967) The Contribution of Agricultural Research to Production. Journal of Farm Economics, 49, 1415-1425. https://doi.org/10.2307/1237038

[4] Alston, J.M., Chan-Kang, C., Marra, M., Pardey, P. and Wyatt, T. (2000) A Meta-Analysis of Rates of Return to Agricultural R \& D: Ex Pede Herculem? Research Report No. 113, IFPRI.

[5] Huffman, W.E. and Evenson, R.E. (2006) Science for Agriculture-A Long-Term Perspective. 2nd Edition, Blackwell Publishing. https://doi.org/10.1002/9780470752555

[6] Fugile, O.K. and Heisey, P.W. (2007) Economic Returns to Public Agricultural Research. EB No. 10, Economic Research Service, USDA.

[7] Coe, D. and Helpman, E. (1995) International R \& D Spillovers. European Economic Review, 39, 859-887.

[8] Johnson, D.K.N. and Evenson, R.E. (1999) R \& D Spillovers to Agriculture: Measurement and Application. Contemporary Economic Policy, 17, 432-456.

https://doi.org/10.1111/j.1465-7287.1999.tb00695.x

[9] Funk, M.F. (2001) Trade and International R \& D Spillovers among OECD Countries. Southern Economic Journal, 67, 725-737. https://doi.org/10.2307/1061461

[10] Mullen, J. (2007) Productivity Growth and the Returns from Public Investment in R \& D in Australian Broadacre Agriculture. The Australian Journal of Agricultural and Resource Economics, 51, 359-384.

https://doi.org/10.1111/j.1467-8489.2007.00392.x

[11] Schimmelpfennig, D. and Thirtle, C. (1999) The Internationalization of Agricultural Technology: Patents, R \& D Spillovers, and Their Effects on Productivity in the European Union and United States. Contemporary Economic Policy, 17, 457-468. https://doi.org/10.1111/j.1465-7287.1999.tb00696.x

[12] Jaffe, A.B. (1986) Technological Opportunity and Spillovers of R \& D: Evidence 
from Firm's Patents, Profits, and Market Value. American Economic Review, 76, 984-1001.

[13] Huffman, W.E., McCunn, A. and Xu, J. (2001) Public Agricultural Research Expenditures with an Agricultural Productivity Emphasis: Data for 48 States, 19271995. Iowa State University, Department of Economics, Staff Paper.

[14] Alston, J.M., Anderson, M.A., James, J.S. and Pardey, P.G. (2010) Persistence Pays: U.S. Agricultural Productivity Growth and the Benefits from Public R \& D Spending. Springer. https://doi.org/10.1007/978-1-4419-0658-8

[15] Alston, J.M., Anderson, M.A., James, J.S. and Pardey, P.G. (2011) The Economic Returns to U.S. Public Agricultural Research. American Journal of Agricultural Economics, 93, 1257-1277. https://doi.org/10.1093/ajae/aar044

[16] Jin, Y. and Huffman, W. (2016) Measuring Public Research and Extension and Estimating Their Impacts on Agricultural Productivity: New Insights from U.S. Evidence. Agricultural Economics, 47, 15-31. https://doi.org/10.1111/agec.12206

[17] McKinsey and Evenson, R.E. (2003) Crop Genetic Improvement Impacts on Indian Agriculture. In: Evenson, R.E. and Gollin, D., Eds., Crop Variety Improvement and Its Effect on Productivity: The Impact of International Agriculture Research, CABI Publishing. https://doi.org/10.1079/9780851995496.0447

[18] Pardey, P.G., Alston, J.M., Kang, C.C., Magalhaes, E.C. and Vosti, S.A. (2006) International and Institutional $\mathrm{R} \& \mathrm{D}$ Spillovers: Attribution of Benefits among Sources for Brazil's New Crop Varieties. American Journal of Agricultural Economics, 88, 104-123. https://doi.org/10.1111/j.1467-8276.2006.00841.x

[19] Fulginiti, L.E. (2010) Estimating Griliches' K-Shift. American Journal of Agricultural Economics, 82, 86-101. https://doi.org/10.1093/ajae/aap011

[20] Nin Pratt, A., Yu, B. and Fan, S. (2008) The Total Factor Productivity in China and India: New Measures and Approaches. China Agricultural Economic Review, 1, 9-22. https://doi.org/10.1108/17561370910915339

[21] Plastina, A. and Fulginiti, L.E. (2012) Internal Rates of Return to R \& D in Agriculture in 48 U.S. States. Journal of Productivity Analysis, 37, 95-113. https://doi.org/10.1007/s11123-011-0252-0

[22] Esposti, R. and Pierani, P. (2003) Public R \& D Investment and Cost Structure in Italian Agriculture, 1960-1995. European Review of Agricultural Economics, 30, 509-537. https://doi.org/10.1093/erae/30.4.509

[23] Onofri, A. and Fulginiti, L.E. (2008) Public Inputs and Dynamic Producer Behavior: Endogenous Growth in U.S. Agriculture. Journal of Productivity Analysis, 30, 13-28. https://doi.org/10.1007/s11123-008-0093-7

[24] Yee, J., Huffman, W.E., Ahearn, M. and Newton, D. (2002) Sources of Agricultural Productivity Growth at the State Level, 1960-1993. In: Ball, V.E. and Norton, G.W., Eds., Agricultural Productivity: Measurement and Sources of Growth, Kluwer Academic Publishers, Boston/Dordrecht/London. https://doi.org/10.1007/978-1-4615-0851-9_8

[25] Birkhauser, D., Evenson, R. and Feder, G. (1989) The Economic Impact of Agricultural Extension: A Review. Economic Development and Cultural Change, 39, 607-650. https://doi.org/10.1086/451893

[26] Evenson, R.E. (2001) Economic Impacts of Agricultural Research and Extension. In: Gardner, B.L. and Rausser, G.C., Eds., Handbook of Agricultural Economics, Elsevier Science.

[27] Huffman, W.E., Ball, V.E., Gopinath, M. and Somwaru, A. (2002) Public R \& D and 
Infrastructure Policies: Effects on Cost of Midwestern Agriculture. In: Ball, V.E. and Norton, G.W., Eds., Agricultural Productivity: Measurement and Sources of Growth, Kluwer Academic Publishers, Boston/Dordrecht/London. https://doi.org/10.1007/978-1-4615-0851-9_7

[28] Schimmelpfennig, D., O’Donnell, C.J. and Norton, G.W. (2006) Efficiency Effects of Agricultural Economics Research in the United States. Agricultural Economics, 34, 273-280. https://doi.org/10.1111/j.1574-0864.2006.00124.x

[29] Antle, J. (1983) Infrastructure and Aggregate Agricultural Productivity: International Evidence. Economic Development and Cultural Change, 31, 609-619. https://doi.org/10.1086/451344

[30] Paul, C.J.M., Ball, V.E., Felthoven, R.G. and Nehring, R. (2001) Public Infrastructure Impacts on U.S. Agricultural Production: Panel Analysis of Costs and Netput Composition. Public Finance and Management, 183-213.

[31] Wang, S.L., Ball, E., Fulginiti, L. and Plastina, A. (2012) Accounting for the Impacts of Public Research, R \& D Spillins, Extension, and Roads in U.S. Agricultural Productivity Growth.

[32] Hurley, T., Rao, X. and Pardey, P. (2014) Re-Examining the Reported Rates of Return to Food and Agricultural Research and Development. American Journal of Agricultural Economics, 96, 1492-1504. https://doi.org/10.1093/ajae/aau047

[33] Brealey, R., Myers, S. and Marcus, A. (2017) Fundamentals of Corporate Finance. Mcgraw-Hill/Irwin Series in Finance, Insurance, and Real Estate. 9th Edition.

[34] Cornes, R. and Sandler, T. (1996) The Theory of Externalities, Public Goods and Club Goods. Cambridge University Press, New York.

https://doi.org/10.1017/CBO9781139174312

[35] U.S. Department of Agriculture, Economic Research Service. Agricultural Productivity in the United States. https://www.ers.usda.gov/data-products/agricultural-productivity-in-the-us/

[36] Ball, V.E., Gollop, F., Kelly-Hawke, A. and Swinand, G. (1999) Patterns of Productivity Growth in the U.S. Farm Sector: Linking State and Aggregate Models. American Journal of Agricultural Economics, 81, 164-179. https://doi.org/10.2307/1244458

[37] Caves, D.W., Christensen, L.R. and Diewert, W.E. (1982) Multilateral Comparisons of Output, Input, and Productivity using Superlative Index Numbers. The Economic Journal, 92, 73-86. https://doi.org/10.2307/2232257

[38] Griliches, Z. (1998) R \& D and Productivity: The Econometric Evidence. The University of Chicago Press, Chicago. https://doi.org/10.7208/chicago/9780226308906.001.0001

[39] Alston, J.M. (2010) The Benefits from Agricultural Research and Development, Innovation, and Productivity Growth. OECD Food, Agriculture and Fisheries Working Papers No. 31.

[40] Huffman, W.E. and Evenson, R.E. (1994) The Development of U.S. Agricultural Research and Education: An Economic Perspective. Iowa State University, Department of Economics, Ames.

[41] Huffman, W.E. (2010) Measuring Public Agricultural Research Capital and Its Contribution to State Agricultural Productivity. Iowa State University, Department of Economics Working Paper 09022.

[42] Wang, S.L. (2014) Cooperative Extension System: Trends and Economic Impacts on U.S. Agriculture. Choices 1 st Quarte, 29, 1-8. 
[43] Sørensen, T. (1948) A Method of Establishing Groups of Equal Amplitude in Plant Sociology Based on Similarity of Species and Its Application to Analyses of the Vegetation on Danish Commons. Biologiske Skrifter/Kongelige Danske Videnskabernes Selskab, 5, 1-34.

[44] Hansen, P. and Jaumard, B. (1997) Cluster Analysis and Mathematical Programming. Mathematical Programming, 79, 191-215.

https://doi.org/10.1007/BF02614317

[45] Ahearn, M., Yee, J. and Bottum, J. (2003) Regional Trends in Extension System Resources. AIB No. 781, Economic Research Service, USDA.

[46] U.S. Department of Agriculture, National Institute of Food and Agriculture. Salary Analyses of State Extension Service Positions.

[47] U.S. Department of Transportation, Federal Highway Administration. Highway Statistical Series. http://www.fhwa.dot.gov/policyinformation/statistics.cfm

[48] Schlenker, W. and Roberts, M.J. (2006) Nonlinear Effects of Weather on Corn Yields. Review of Agricultural Economics, 28, 391-398. https://doi.org/10.1111/j.1467-9353.2006.00304.x

[49] Schlenker, W. and Roberts, M.J. (2008) Estimating the Impact of Climate Change on Crop Yields: The Importance of Nonlinear Temperature Effects. NBER Working Paper No. 13799.

[50] Levin, A., Lin, C.F. and Chu, C.J. (2002) Unit Root Tests in Panel Data: Asymptotic and Finite-Sample Properties. Journal of Econometrics, 108, 1-24. 


\section{Appendix}

Table A1. Average input price elasticities and output cost elasticities, 48 states, US Agriculture, 1980-2004, alternative Spill-in models.

\begin{tabular}{|c|c|c|c|c|c|c|c|c|}
\hline \multirow[b]{2}{*}{ Elasticity } & \multicolumn{2}{|c|}{ Model 1} & \multicolumn{2}{|c|}{ Model 2} & \multicolumn{2}{|c|}{ Model 3} & \multicolumn{2}{|c|}{ Model 4} \\
\hline & mean & $\begin{array}{l}\text { standard } \\
\text { deviation }\end{array}$ & mean & $\begin{array}{l}\text { standard } \\
\text { deviation }\end{array}$ & mean & $\begin{array}{l}\text { standard } \\
\text { deviation }\end{array}$ & mean & $\begin{array}{l}\text { standard } \\
\text { deviation }\end{array}$ \\
\hline \multicolumn{9}{|c|}{ Input own price elasticity } \\
\hline$\eta_{\mathrm{A}}$ & -0.4538 & 0.1229 & -0.4244 & 0.1511 & -0.4443 & 0.1386 & -0.4432 & 0.1362 \\
\hline$\eta_{\mathrm{M}}$ & -0.1724 & 0.0244 & -0.1582 & 0.0224 & -0.1675 & 0.0257 & -0.1571 & 0.0249 \\
\hline$\eta_{\mathrm{K}}$ & 0.1545 & 0.2457 & 0.1607 & 0.2412 & 0.1363 & 0.2467 & 0.1526 & 0.2444 \\
\hline$\eta_{\mathrm{L}}$ & -0.2163 & 0.1295 & -0.1781 & 0.1583 & -0.1866 & 0.1609 & -0.1815 & 0.1580 \\
\hline \multicolumn{9}{|c|}{ Input cross elasticity } \\
\hline$\eta_{\mathrm{AM}}$ & 0.1988 & 0.1146 & 0.2206 & 0.1172 & 0.2038 & 0.1226 & 0.2064 & 0.1191 \\
\hline$\eta_{\mathrm{A} \mathrm{K}}$ & 0.1170 & 0.0350 & 0.1037 & 0.0366 & 0.1174 & 0.0357 & 0.1164 & 0.0352 \\
\hline$\eta_{\mathrm{AL}}$ & 0.1380 & 0.0644 & 0.1001 & 0.0746 & 0.1230 & 0.0699 & 0.1203 & 0.0704 \\
\hline$\eta_{\mathrm{M} \mathrm{A}}$ & 0.0568 & 0.0345 & 0.0623 & 0.0343 & 0.0579 & 0.0341 & 0.0586 & 0.0342 \\
\hline$\eta_{\mathrm{M} \mathrm{K}}$ & -0.0133 & 0.0366 & -0.0200 & 0.0369 & -0.0102 & 0.0369 & -0.0175 & 0.0371 \\
\hline$\eta_{\mathrm{M} \mathrm{L}}$ & 0.1289 & 0.0554 & 0.1159 & 0.0553 & 0.1198 & 0.0560 & 0.1160 & 0.0559 \\
\hline$\eta_{\mathrm{K} \mathrm{A}}$ & 0.1063 & 0.0364 & 0.0950 & 0.0367 & 0.1065 & 0.0357 & 0.1058 & 0.0360 \\
\hline$\eta_{\mathrm{K} \mathrm{M}}$ & -0.0701 & 0.1513 & -0.0929 & 0.1555 & -0.0589 & 0.1518 & -0.0841 & 0.1551 \\
\hline$\eta_{\mathrm{K} \mathrm{L}}$ & -0.1908 & 0.1197 & -0.1629 & 0.1125 & -0.1839 & 0.1234 & -0.1743 & 0.1183 \\
\hline$\eta_{\mathrm{LA}}$ & 0.0771 & 0.0351 & 0.0562 & 0.0386 & 0.0684 & 0.0368 & 0.0669 & 0.0369 \\
\hline$\eta_{\mathrm{LM}}$ & 0.2634 & 0.0634 & 0.2315 & 0.0739 & 0.2405 & 0.0738 & 0.2315 & 0.0743 \\
\hline$\eta_{\mathrm{L} \mathrm{K}}$ & -0.1243 & 0.0880 & -0.1095 & 0.0909 & -0.1222 & 0.0986 & -0.1168 & 0.0946 \\
\hline \multicolumn{9}{|c|}{ Output cost elasticity } \\
\hline$\eta_{\mathrm{V}}$ & 0.4211 & 0.0673 & 0.4422 & 0.0784 & 0.4407 & 0.0739 & 0.4497 & 0.0757 \\
\hline$\eta_{\mathrm{C}}$ & 0.3640 & 0.0864 & 0.3759 & 0.0921 & 0.3699 & 0.1026 & 0.3688 & 0.1042 \\
\hline$\eta_{\mathrm{O}}$ & 0.0046 & 0.0910 & -0.0006 & 0.1170 & 0.0080 & 0.1171 & 0.0022 & 0.1142 \\
\hline Hessian & -0.0004 & 0.0017 & -0.0003 & 0.0014 & -0.0004 & 0.0016 & -0.0003 & 0.0016 \\
\hline
\end{tabular}

Note 1: The spill-in RD stocks are based on production region, geographical distance, un-weighted production profile, and correlation weighted production cluster for Model 1 to Model 4, respectively. Note 2: V stands for livestock, C for crops, O for other farm related goods and services, A for land, L for labor, $\mathrm{M}$ for materials, $\mathrm{K}$ for capital. 